
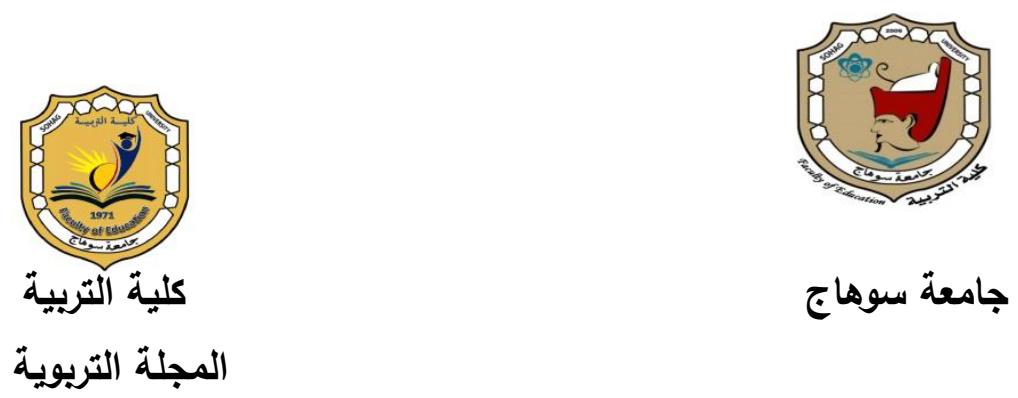

\title{
الدافعية العقلية وعلاقتها بجودة الشخصية لدي المتفوقين دراسيًا من طلاب الصف الأول الثانوي
}

$$
\begin{aligned}
& \text { إعداد } \\
& \text { د/ هلدي حسن أ حمد عبل المانك } \\
& \text { مدرس علم التفس التريوي - كلية التربية التوعية } \\
& \text { جامعة القاهرة }
\end{aligned}
$$


المستخلص

يـهدف البحث الحـالى إلى التعرف على مستوي الدافعيـة العقليـة ومستوي الجـودة الثخصية لدي المتفوقين دراسياً ، وتقصي العلاقة بين الدافعية العقلية والجودة الثخصية للـيهم، والتعرف على الفـروق بـين الـكور والإنـاث فـي كل مـن الدافعيـة العقليـة والجـودة الثخصية، ولتحقيق أهداف البحث تم استخدام المنهج الوصفي وتطبيق مقياس كاليفورنيا للافعية العقلية مع إجراء بعض التعديلات، ومقياس الجودة الثخصية من إعداد الباحثة.

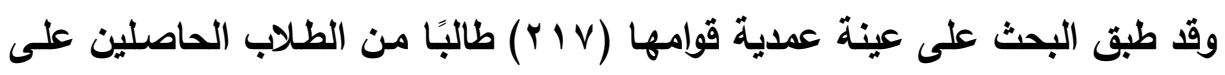

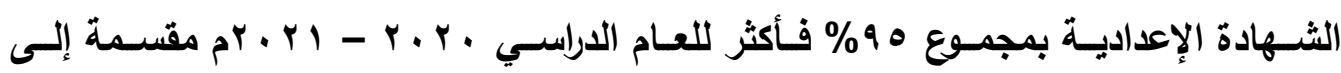
(111)

وتوصـل البحث إلى عدة نتائج منها: وجـود علاقـة ارتباطيـة موجبـة دالـة

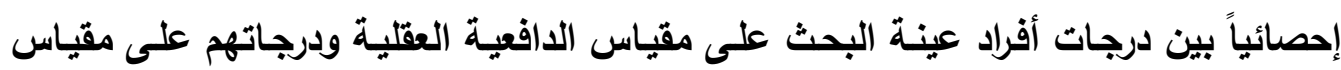
الجودة الثخصية، عدم وجود فروق دالة إحصائياً بين متوسطي الذكور والإناث في الارجة

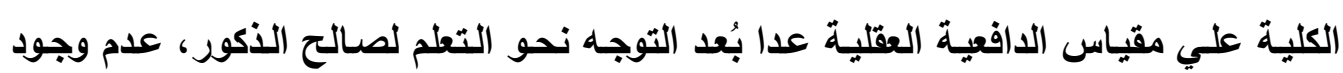
فروق في أبعاد الجودة الشخصية بين الأكور والإناث.

الكلمات المفتاحية: الدافعية العقلية - الجودة الشخصية - المتفوقين دراسياً. 


\title{
Mental Motivation and its Relationship to Personality Quality among the Academically Outstanding Students of the First Year of Secondary School
}

\begin{abstract}
The research aims to: identify the level of mental motivation and the level of personal quality among academically talented students, and investigate the relationship between the mental motivation and the personal quality for them, and to identify the differences between males and females in each of the dimensions of mental motivation and personal quality of academically superior students.

And to achieve the objectives of the research the descriptive approach method, and the California Mental Motivation Scale was used with some modifications, and the personal quality scale was prepared by the researcher.

The research was applied to a deliberate sample of $(Y \backslash V)$ students who obtained a preparatory certificate with a total of $\% 90$ or more for the academic year $r \cdot r,-r \cdot r \cdot A D$, divided into ( 111$)$ female students and $(1 \cdot T)$ male students.

The results indicated to the existence of a positive, statistically significant correlation between the average scores of the research sample responses on the mental motivation scale and their average scores on the personal quality scale, the absence of statistically significant differences between the general average of the research sample response scores on the mental motivation dimensions scale due to a variable Gender, except dimension of orientation towards learning in favor of males, there are no differences in the dimensions of personal quality between males and females.
\end{abstract}

Keywords: mental motivation - personal quality - academically superior students. 


\section{مقدمة}

في خضم ما يحدث في العالم من تطورات وتفجرات علمية ومعرفية تكنولوجيا متلاحقة

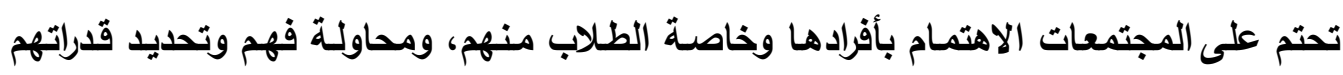

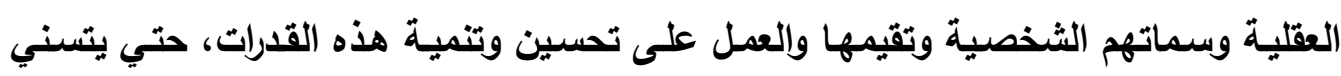
لهم مواكبة هذه التطورات العلمية والمعرفية بمهارة وثقة.

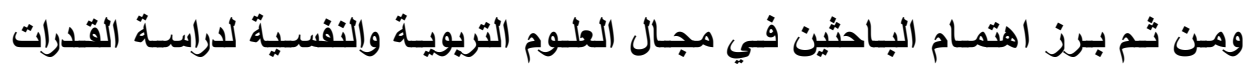
والمهارات العقلية إلى جاتب السمات الثخصية للأفراد ولاسيما الطلاب.

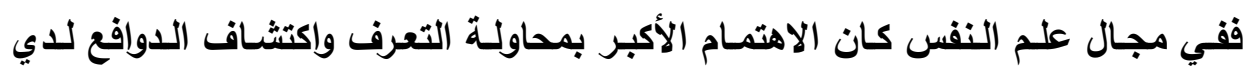

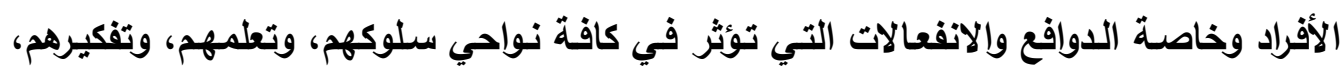
وإبداعهم، وأداء أعمالهم، وسماتهم الثخصية وجودتها.

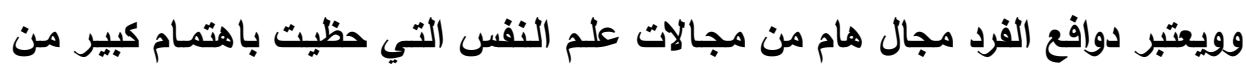

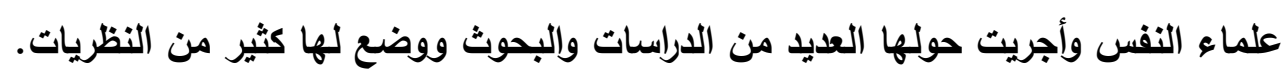

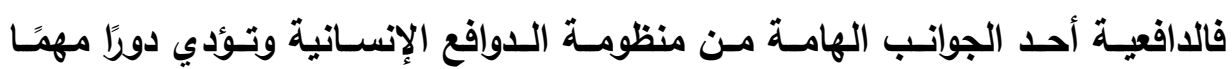

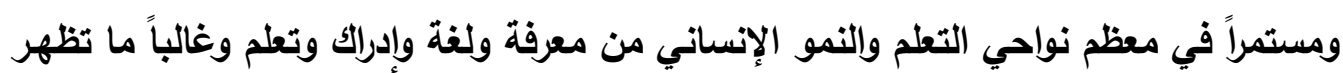

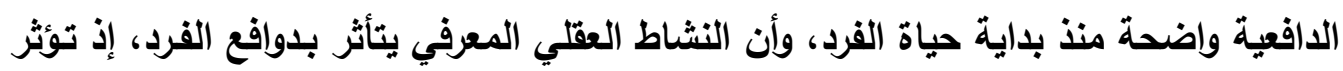

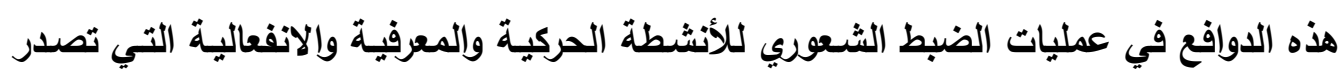
عن الفرد، ومن ثم يمكن القول أن هذه الأنثطة تكون محكومة بطبيعة الدوافع الإنسانية من

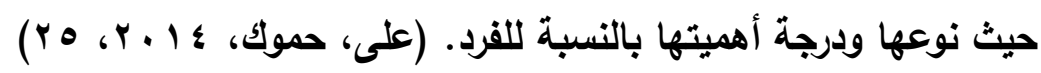
وينظر التريويون إلى الدافعية على أنها هذف تريوي ينثده أي نظام تعليمي، ولا سيما

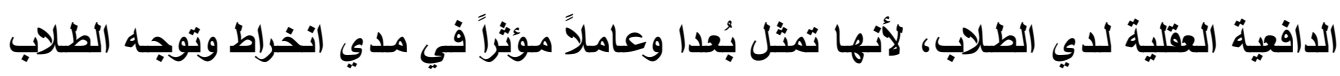
نحو التعليم، ومشاركتهم المعرفية في العملية التعليمية.

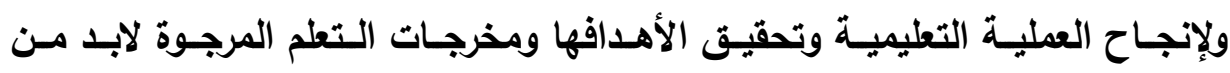
الاهتمام بدافعية الطالب الذي يمثل محور العملية التعليمية ولاسيما الدافعية العقلية لديه.

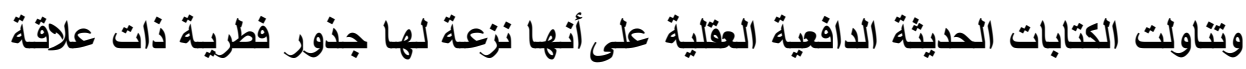
بغريزة حب الاستطلاع والاكتثاف التي تظهر بشكل جلَّي في سلوك الإنسان ولا سيما الطلاتع

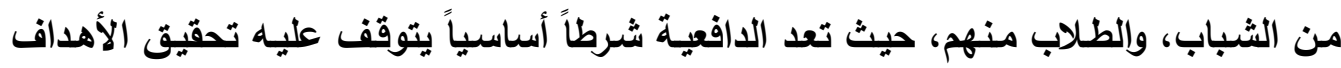


التعليميـة في مجـالات التعلم المتعددة، سـواء في تحصيل المعلومـات والمعـارف (الجانـب المعرفي)، أو تكوين الاتجاهـات والقيم (الجانب الوجداني)، أو في تكوين المهارات المختلفة التي تخضع لعوامل التدريب والممارسة (الجانب الحركي) (شواشرة، V . . r، ؛ ). فالدافعيـة العقليـة شـكلت بُعدا مهمـا في حيـاة الطلبـة عامـة، والطلبـة في المرحلـة الثانوية خاصـة، لما لها من أهمية بالغة في حياتهم الدراسية، إذ يتعرض الطلبة إلى أنواع متباينة من المعلومات التي يتلقونها، أو يحصلون عليها من مصادر كثيرة، كما يواجه الطلبة العديد من المشكلات العلمية والحياتية، يكون التناقض هو السمة الأساسية فيها، الأمر الذي يفرض على الطلبة ممارسة مجموعة من مهارات الدافعية العقلية مثل مهارة التركيز العقلّي، والتوجها نحو التعلم، وحل المشكلات إبداعياً وإلتكامـل المعرفي، وإلتي تشكل بمجملها أبعاد

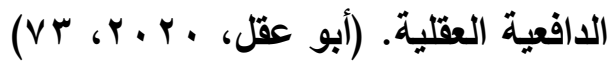
ويواصل الطالب ذو الدافعيـة العقلية أداء الأنشطة الدراسية والحياتية باستمرار طوال حياته ولا يؤثئر عليه الإخفاق في أي مهمـة، بل يكون ذلك دافعاً للوصول إلى غايته ويكون الهُف النهائي هو المحرك الأساسي لأدائه وأنشطته، ولا يستطيع الطالب تحقيق هدفه إلا إذا لهان

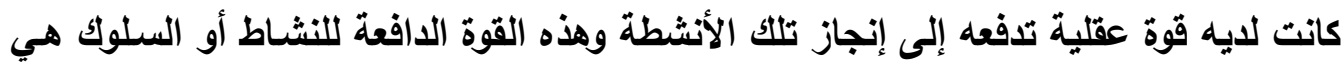

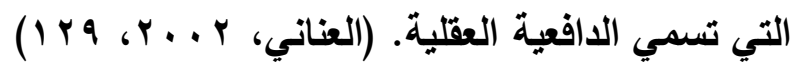
ومما لا شك فيه أن الطلاب المتفوقين دراسياً هم ثروة من الثروات البشرية ذات أهمية كبيرة للمجتمع، تنعقد عليهم الأمسال والطموحات المستقبلية لبنـاء المجتمع وتطوره، ومن ثم ترون يجب أن نتعرف على سمات وخصائص هذه الفئة ونعتني بها لزيادة تفوقها وتوجيهها إلى

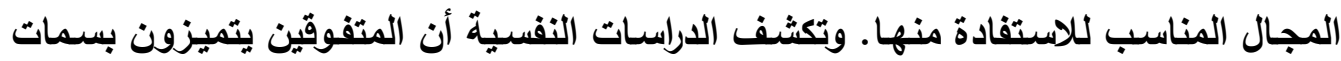

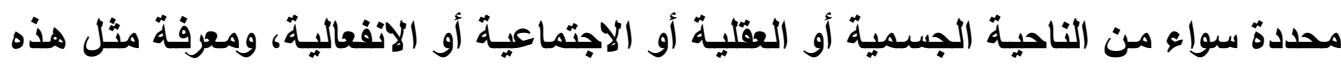
السمات يساعدنا على التعرف عليهم، كما أنه يجعلنا نهيئ المناخ المناسب لرعايتهم.

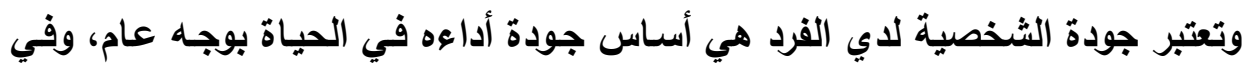

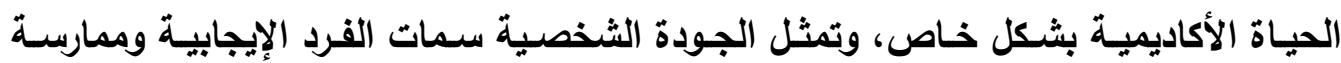

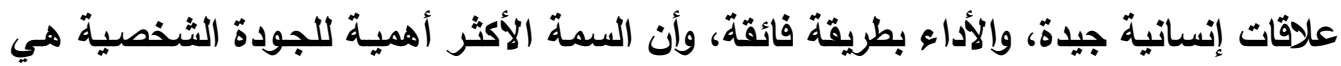

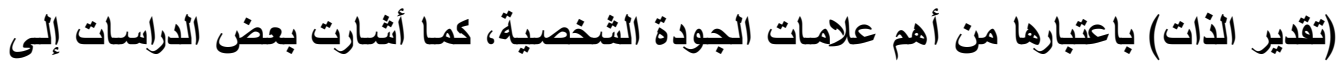

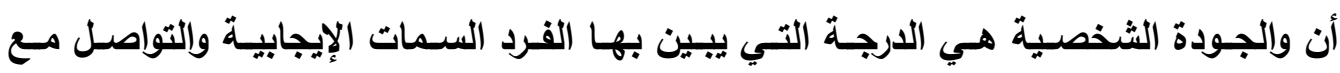


الآخرين بطريقة فعالة ليكون عملاً متميزاً، فضلاً عن ذلك هي مؤشر للالالة على التوازن بين

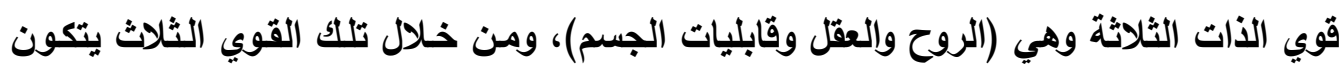

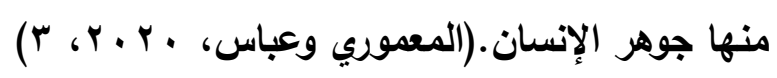

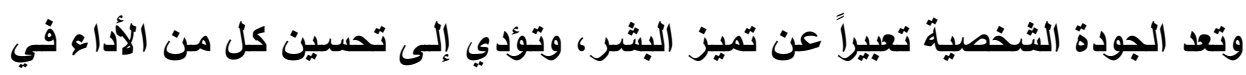

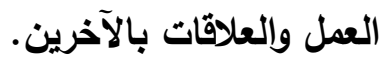

وتمثل الجـودة الثخصية أهميـة كبيرة في المجتمعات المتقدمة حيث تبـأ الجـودة

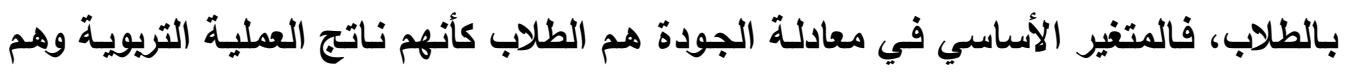

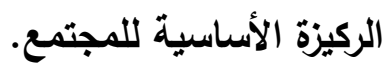

ومما سبق يتضح أن المتفوقين دراسياً من الفئات التي تتميز بدافعية عقلية إيجابية

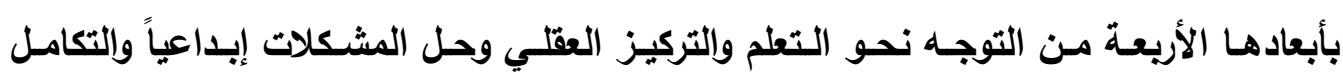

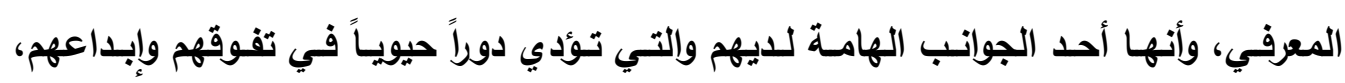

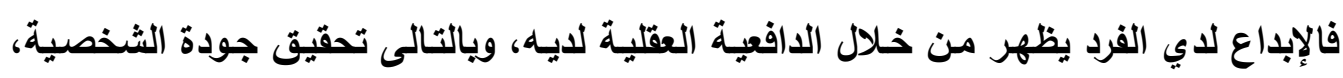
وهذا هو ما يحاول البحث الحالى التأكد من صحته. ومن هذا المنطلق سعي البحث الحالي إلى دراسة العلاقة بين الدافعية العقلية والجودة الثخصية لاي المتفوقين دراسياً.

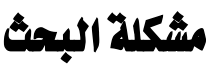

نثأت فكرة البحث الحالى من اهتمام الباحثة بفئة المتفوقين دراسياً ومحاولة التعرف

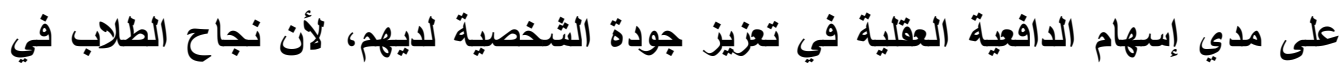

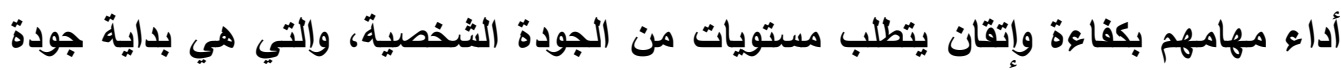

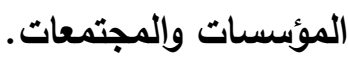

ونظراً لأهمية الدافعية العقلية ووفقاً لتوصيات الدارسات والبحوث في مجال علم النفس والدات

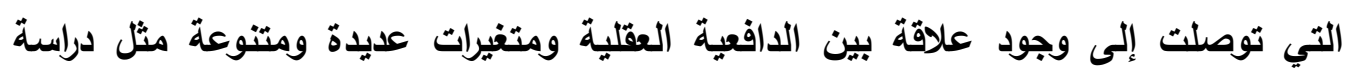

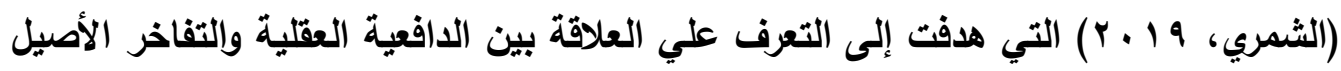

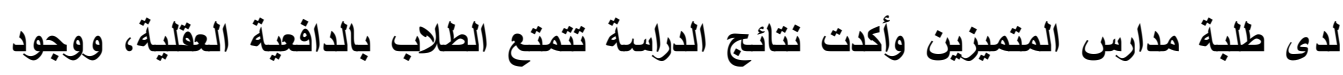
علاقة دالة إحصائياً بين الدافعية العقلية والتفاخر الأصيل، وكما سعت دالتئية (الحميدي،9 1 ب) إلى التعرف على مستوي الدافعية العقلية لاي الطلاب الموهوبين والفروق 
في الدافعية العقلية لايهم وفقاً للنوع، وأظهرت النتائج أن درجة الدافعية العقلية لاي الطلبة

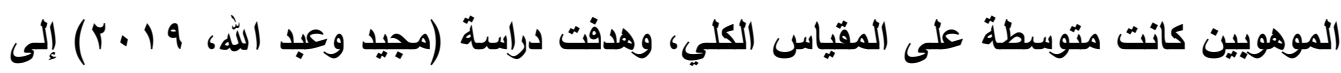

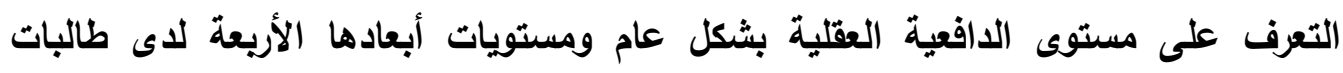

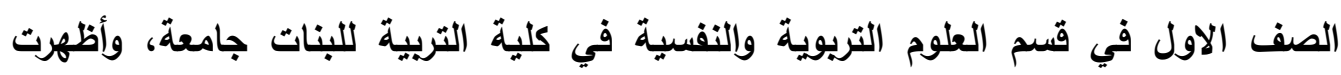

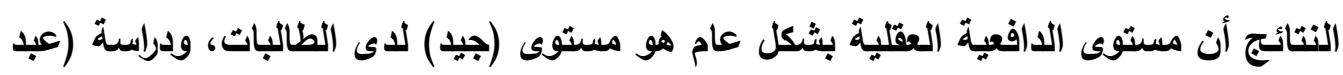

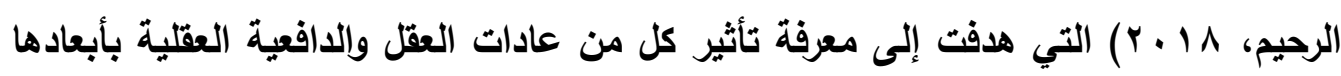

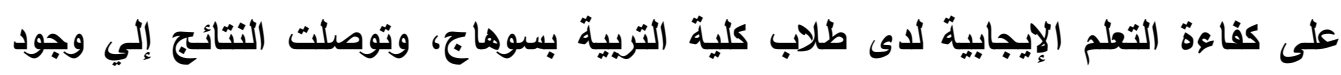

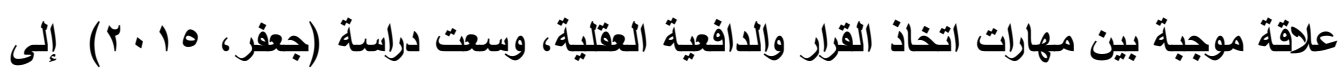

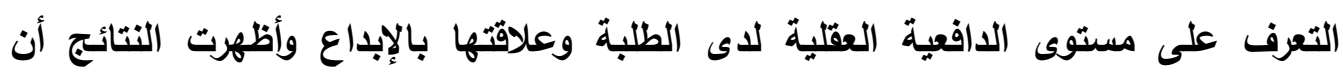

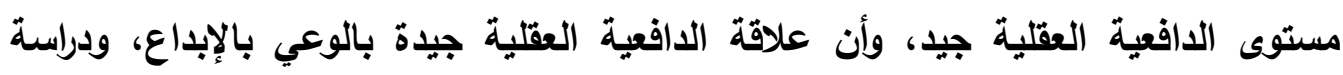

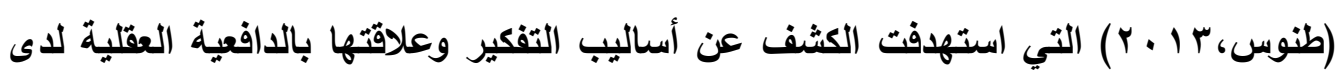

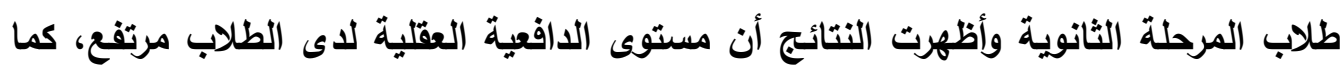

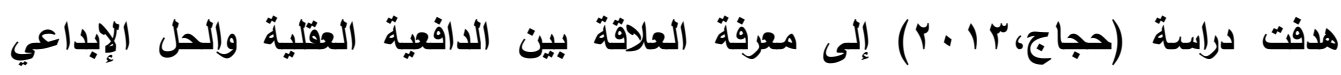

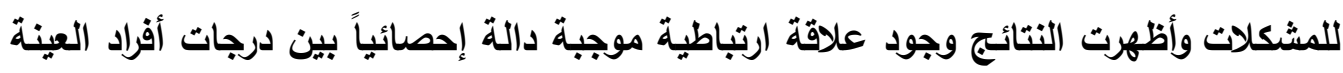

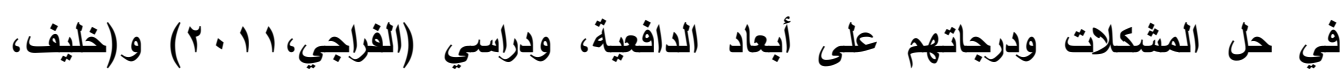

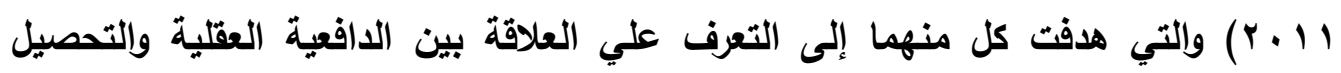
الدراسي، وتوصلت نتائج الدارستين إلي وجود علاقة ذات دلالة إحصائية بين الدافعية العقلية والتحصيل الاراسي، وكما أجري (Vermeer, Boekaerts, \& Seegers,2000) دراسة هدفت إلى بحث أثث اللافعية العقلية والجنس في سلوك حل المسائل الحسابية، وأظهرت النتائج وجود ارتباط بين الدافعية العقلية وسلوك حل المشكلات، ودراسة ( Garcia \&) Pintrich,1992 التي هدفت إلى دراسة علاقة التفكير الناقد بالدافعية واستراتيجيات التعلم وأظهرت النتائج وجود علاقة ارتباطية موجبة بين الدافعية العقلية والتفكير الناقد.

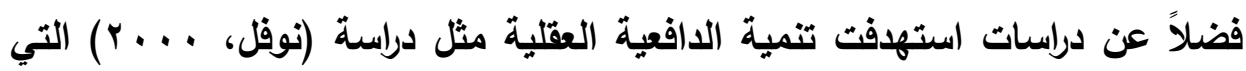

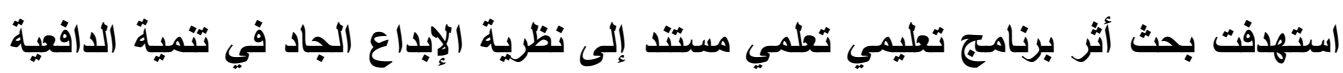

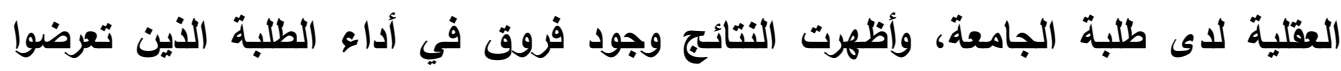
للبرنامج على مقياس كاليفورنيا للاففية العقلية بأبعاده المختلفة. 
ومن ناحية أخري نجد - ندرة الأبحاث والدراسـات - في حدود مـا تم الاطلاع عليهالتي تناولت متغير الجودة الشخصية. وقد تناولت بعض الاراسات والبحوث الجودة الشخصية وعلاقتها بمتغيرات أخري مثل دراسة (مصطفى، 2019) التي هدفت إلى اكتثاف العلاقة بين بعض أنماط الذكاء ومكونات

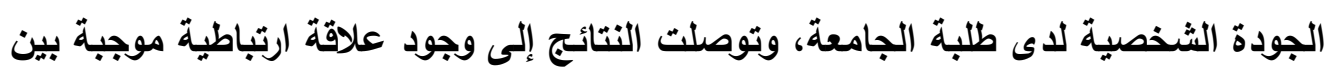

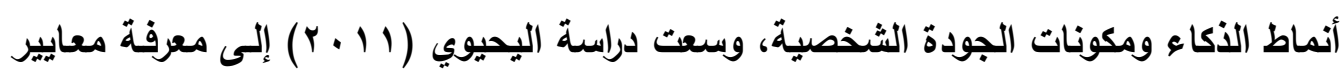

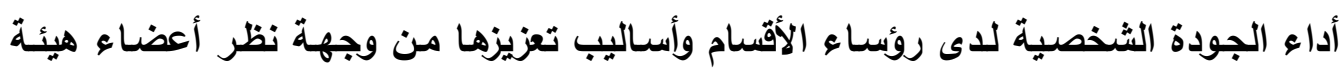

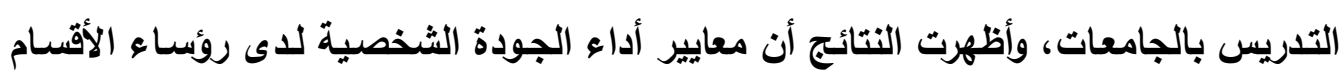
بالجامعات السعودية بلغت درجة متوسطة. وأجري (Pitt, et al, 2014) دراسة سعت إلى التعرف على العلاقة بين الجودة الثخصية لاي الطلاب وأدائهم الأكاديمي وسلوكياتهم ومستوى تقدمه الدراسي وإلكفاءة، وأسفرت النتائج عن وجود علاقة ارتباطية بين متوسطات درجات أفراد العينة على مقياس الادئ الجودة الثخصية في بُعد ضبط النفس والمرونة وسمات العزلة والثقة والمشاركة ودرجات الأداء الأكاديمي. وفي إطار الاهتمام بالمتفوقين دراسياً أجريت العديد من الدراسات والبحوث لدراسة

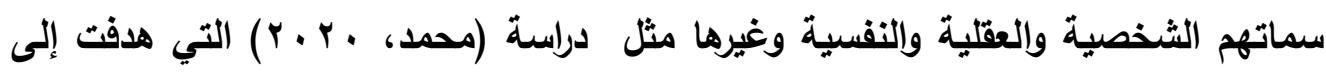
الكثف عن العلاقة بين المرونة المعرفية، وإلكفاعة الأكاديمية المدركة لاى الطلاب المتفوقين عقلياً، وأظهرت النتائج وجود علاقة ذات دلالة إحصائية بين الارجة الكلية للمرونة المعرفية، والدرجة الكلية للكفاءة الأكاديمية المدركة لدى الطلاب المتفوقين عقلياً، كما هدفت دراسة دلانة (البيطار، Y 1 • Y) إلى الكثف عن السمات الثخصية التي تميز الطلبة المتفوقين دراسياً عن غير المتفوقين في الصف الأول الثانوي، وتوصلت الدراسة إلى تميز الطلبة المتفوقون عن غير المتفوقين في أنهم أكثر ذكاء وحكمة وحذاقة، وأكثر واقعية وموضوعية، وأكثر هدوياً

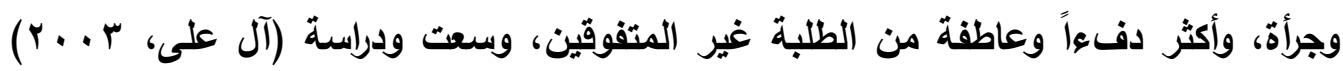
إلى تحديد السمات المعرفية وغير المعرفية التي تتميز بها الطالبات المتفوقات عقلياً وأكاديمياً عن الطالبات المتوسطات ودون المتوسطات في الصف الأول الثانوي، وأسفرت النتائج عن وجود فروق ذات دلالة إحصائية بين المجموعات الثلاث في جميع السمات الرئيسية، كما 
أجري(المطيري، . . . ب) دراسة هدفت إلى الكثف عن الذكاء الاجتماعي لاي المتفوقين

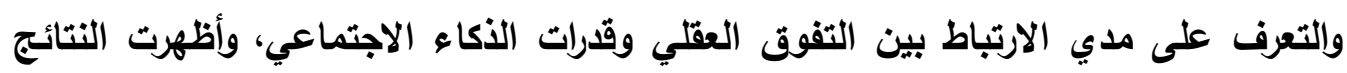

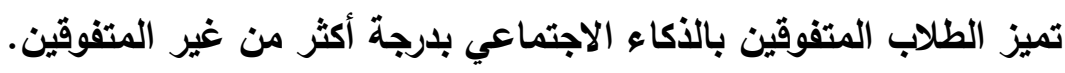

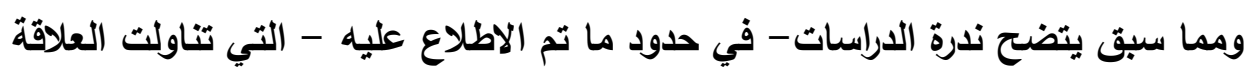
بين الدافعية العقلية والجودة الثخصية. لألك تتحدد مشكلة البحث في التساؤل الرئيسي التالى:

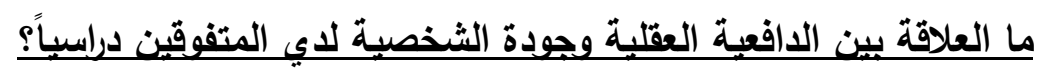
ينبثق من هذا التساؤل عدة تساؤلات منها:

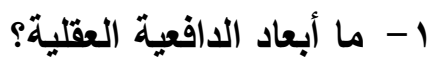

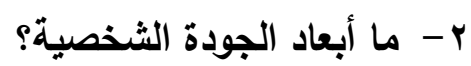
r- ما العلاقة بين الدافعية العقلية والجودة الثخصية لادي المتقوقين دراسياً من طلاب الصف الأول الثانوي؟ ع - ما الفرق بين الأكور والإناث في الادفعية العقلية ؟ ه- ما الفرق بين الذكور والإناث في الجودة الثخصية ؟ الإن في الفورية أهدافالبحثب يهذف البحث الحالى إلى: - بلى - التعرف على مستوي الدافعية العقلية لاي المتفوقين دراسياً. - التعرف على مستوي الجودة الثخصية لاي المتفوقين دراسياً.

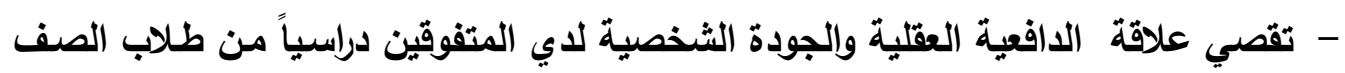

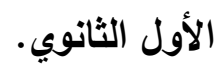

- التعرف على الفروق بين الذكور والإناث في كل من الدافعية العقلية والجودة الثخصية لديهم. 


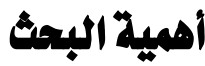

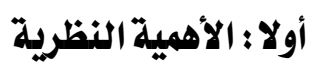

تمثلت الأهمية النظرية للبحث في أهمية:

- الاففية العقلية لاي المتفوقين التي تمثل قوة دافعة لحدوث التعلم، فلا يحدث التطم في في

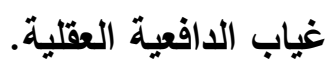

- الجودة الثخصية لاي المتفوقين، والتي يمكن اكتسابها وتعزيزها. - مـا قدمه البحث من تأصيل نظري لمتغيري البحث (الدافعية العقلية والجودة الثخصية) لاي طلاب الصف الأول الثانوي المتفوقين دراسياً.

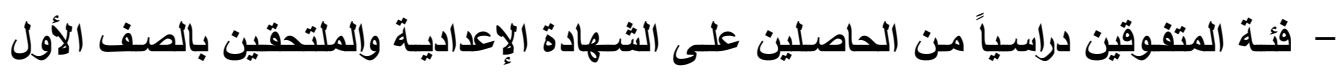

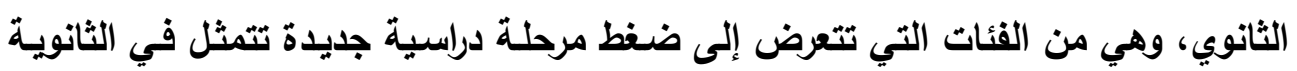
العامة والتي لها تأثيرات على جودة الثخصية بثكل سلبي. ثانياً: الأهية التطبيقية تتضح الأهمية التطبيقية للبحث من خلال أهمية: - توجيه أنظار المعنيين بمجال العلوم التريوية وإلنفسية نحو الاهتمام بتنمية الدافعية العقلية وتعزيز الجودة الثخصية لاي الأفراد.

- من المتوقع أن يعزز هذا البحث فكرة استحداث برامج دراسية تنمي الدافعية العقلية وتعزز جودة الثخصية لاي الطلاب في المراحل الاراسية المختلفة. - توفير أدوات لقياس الدافعية العقلية والجودة الثخصية يمكن تطبية الطبة الثها في أغراض تريوية ونفسية مختلفة.

- مساعدة الباحثين في إجراء بحوث ودراسات تتناول العلاقة بين الدافعية العقلية والجودة الثخصية لاي غير المتفوقين دراسياً، في مراحل دراسية مختلفة. 


\section{مجداث البعث}

- المحددات البشرية: تتكون من المتفوقين دراسياً من الطلاب الحاصلين على الثـهادة

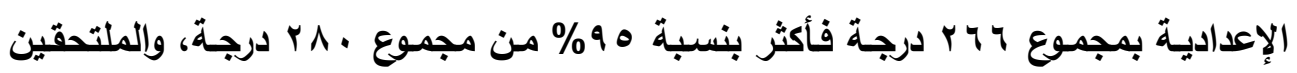

حديثاً بالصف الأول الثانوي.

- المحدات المكانية: تتمثل في محافظة الجيزة.

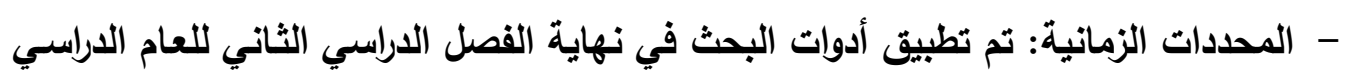
Pr.r -r.r.

- المددات الموضوعية: الدافعية العقلية - الجودة الثخصية.

فروض البحث البه

الفرض الأول: توجد علاقة ارتباطية موجبة دالة إحصائياً بين درجات أفراد عينة البحث

على مقياس الدافعية العقلية ودرجاتهم على مقياس الجودة الثخصية. الفرض الثاني: لا توجد فروق دالة إحصائياً بين متوسطي الذكور والإناث في الدرجة الكلية علي مقياس الدافعية العقلية. الفرض الثالث: لا توجد فروق دالة إحصائياً بين متوسطي الذكور والإناث في الدرجة الكلية علي مقياس الجودة الثخصية.

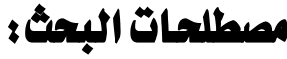

- الدافعيـة العقلية (Mental Motivation): هي التحفيز العقلـي داخلياً للفرد للانخراط و المشاركة في الأنثطة المعرفية التي تتطلب الاستعمال الواسع للعمليات العقلية لإيجاد حل للمشكلات أو اتخاذ القرارات أو تقييم المواقف (McInerney, 2001, 46).

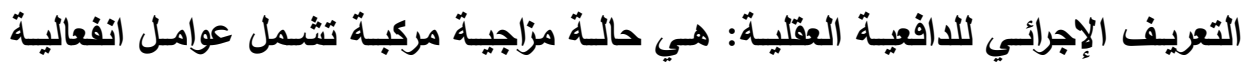

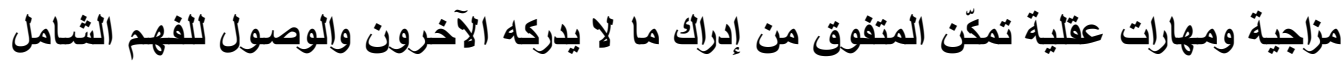

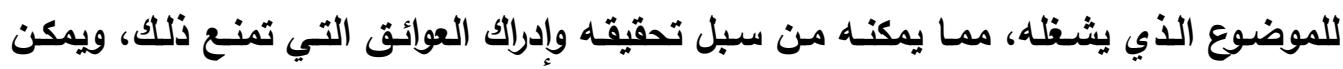

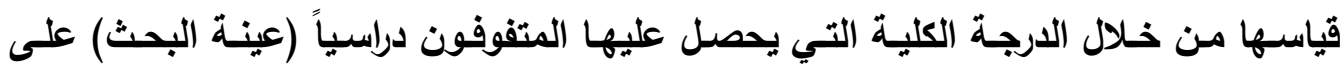

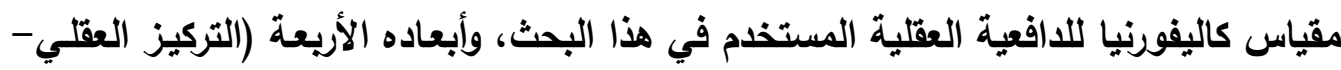
التوجه نحو التعلم- حل المشكلات إبداعياً - التكامل المعرفي). 
- الجودة الثخصية (Personal Quality): مفهوم مركب يجسد سمات الثخصية الإيجابية التي تعكس تقدير الفرد لذاته، وممارسـة المسؤولية الثخصية، وروئيته الذاتيـة،

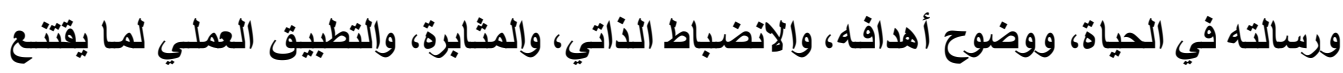

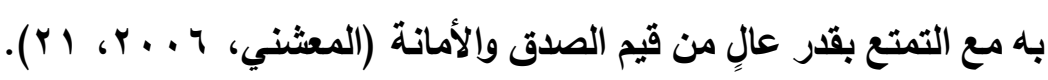

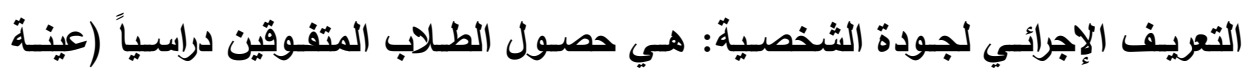

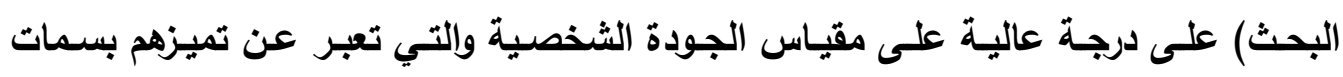

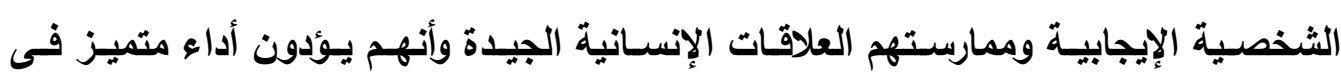

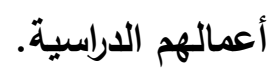

- المتفوقون دراسياً (Outstanding Students): هم العناصر البارزة من الطلبة

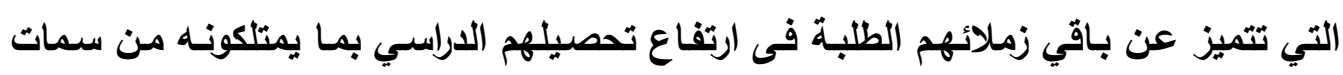

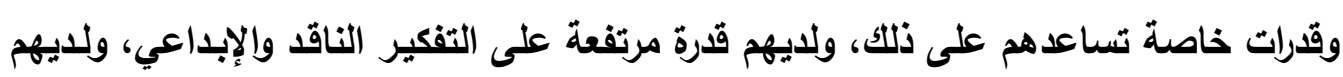

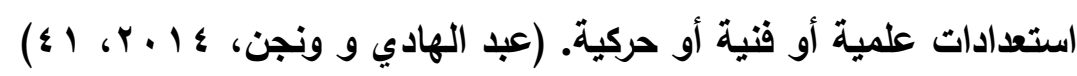

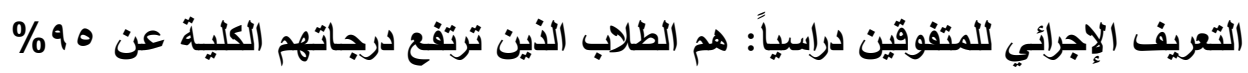
في جميع الاختبارات الدراسية بمرطلة الثهادة الإعدادية. الإطارالنظري

\section{مثهوم الدافية المقلية}

يعرف Giancarlo and Facione (1998) مصماً مقياس الافعية العقلية

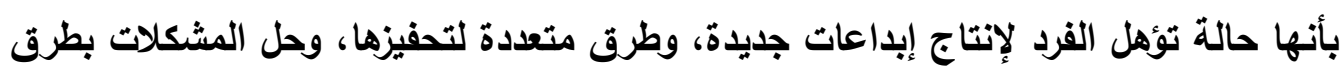
مختلفة تبدو غير منطقية، وتتكون من أريعة أبعاد هي: التوجه نحو التهو التعلم، الحل الإبداعي للمشكلات، التركيز العقلي، التكامل المعرفي. وعرف كل من Giancarlo ,Blohm and Urdan (2004) الدافعية العقلية بأنها رغبة الفرد ونزعته نحو استخدام قدراته بالتفكير، وقابليته الإبداعية. (عبد الحميد وشافعي، بانية

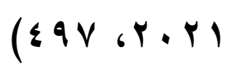

وقد عرف دي بونو الدافعية العقلية بالحالة التي تؤهل صاحبها لانجاز إبداعات

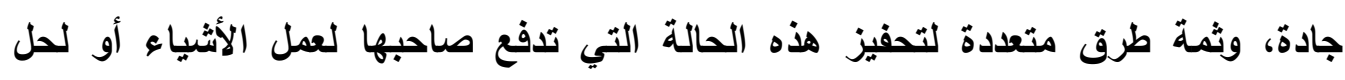

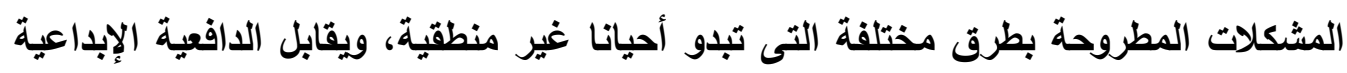


الجمود العقلي، ويؤكد دي بونو أن الدافعية العقلية تجعل من المتطمين مهتمين بالأعمال

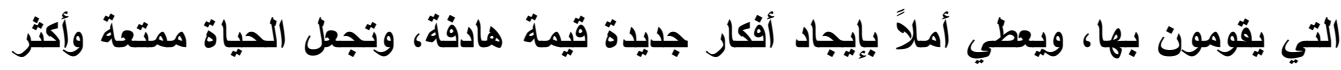

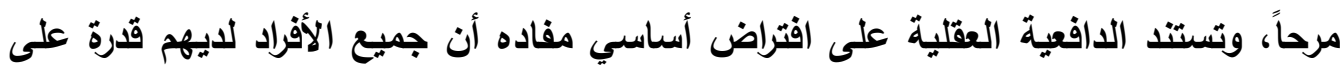

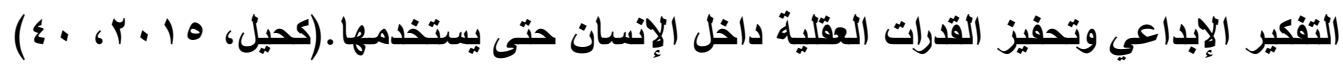
ويشير مصطلح الدافعية (Motivation) إلى مجموعة الظروف الداخلية والخارجية الإنية

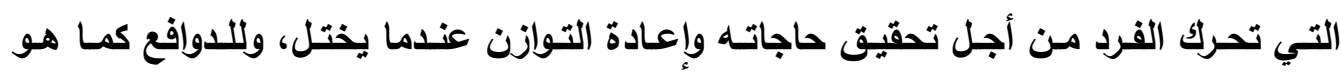

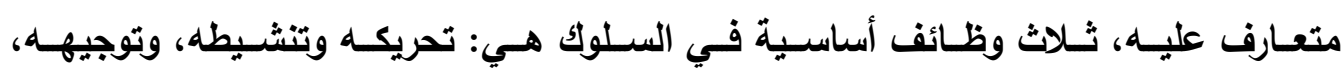

والمحافظة على استدامته حتي تثبع الحاجة ويعود التوازن. (Govern,2004, 55)

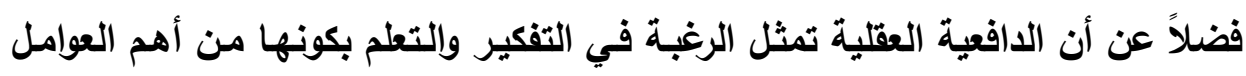

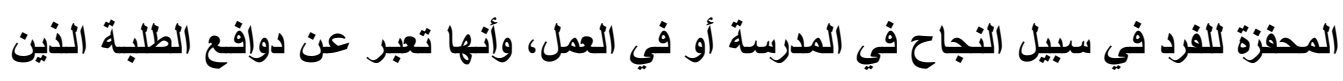

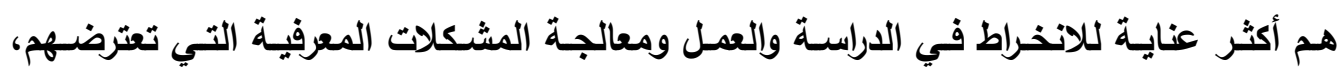

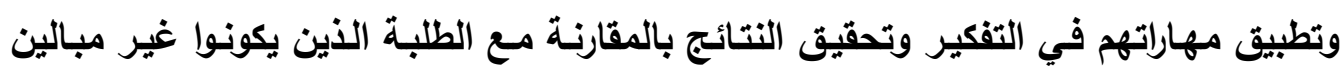

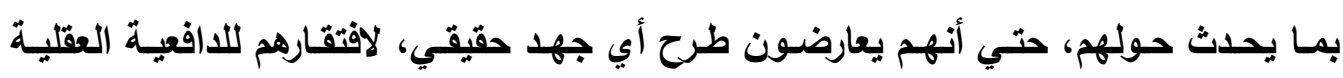

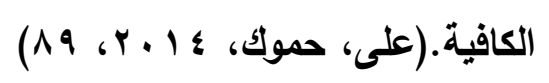

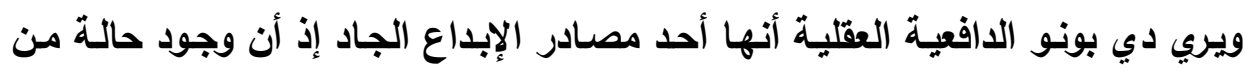

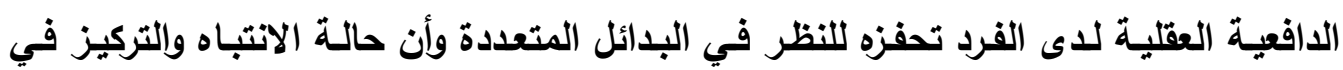

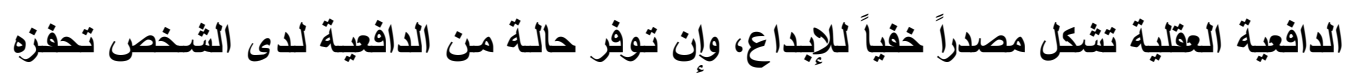
(Kurum, 2007,86) للنظر إلى بدائل أكثرة

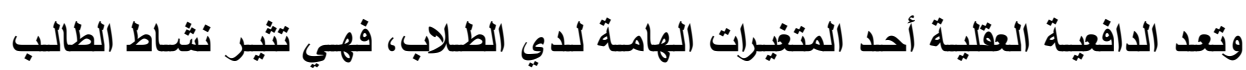

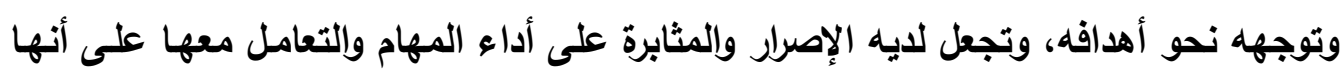

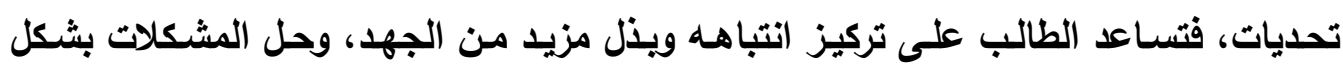

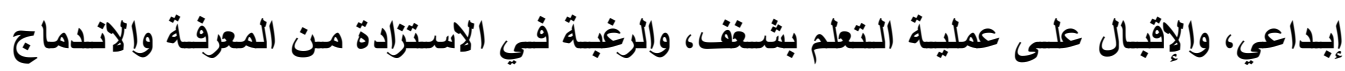

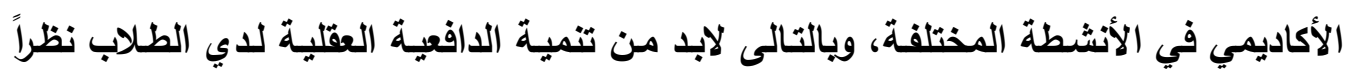

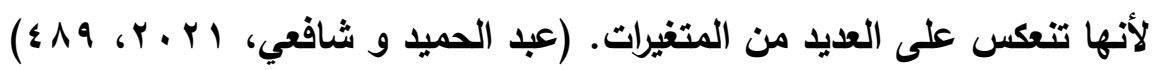




\section{أبعاد الداقية العقلية}

تتكون الأفعية العقلية من أريعة أبعاد أو محاور وهي:

أ. التركيز العقلي (Mental Focus)

ب. التوجه نحو التطلم (Learning Orientation)

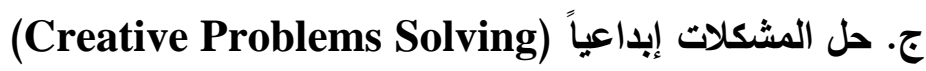

د. التكامل المعرفي (Cognitive Integrity)

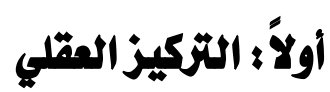

يتصف المتطلم الذي يتميز بالقدرة على التركيز العقلي بأنه شخص مثابر مركَز

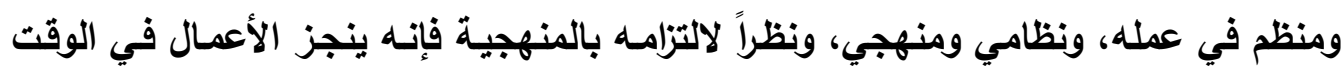

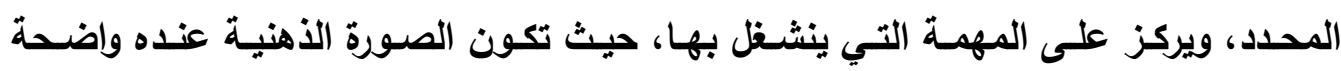
وينصب تركيزه علي موضوع النشـاط ممـا يشعر بالراحة تجاه عملية حل المشكلات واتخـاذ

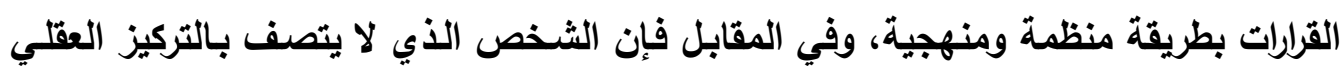
هو الذي يكون أكثر عشوائية في تفكيره، غير منظم، غير مركز ويتثتت بسـهولة. (رف الله، (rTV r r. IT

ثانيا : التوجه نحو التعلم يتمثل هذا العامل في قدرة المتعلم على توليد دافعية لزيادة قاعدة المعارف لديه، حيث يثمن التعلم من أجل التعلم، باعتباره وسيلة لتحقيق السيطرة على المهمات التعليمية،

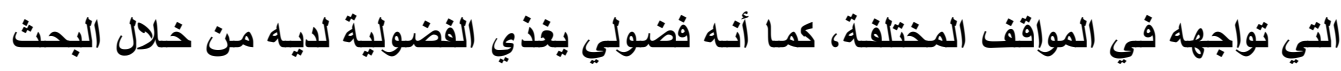

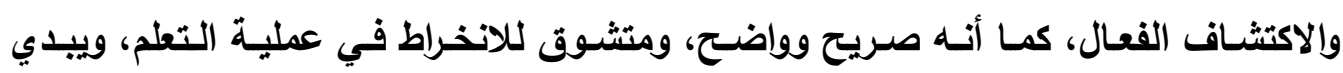

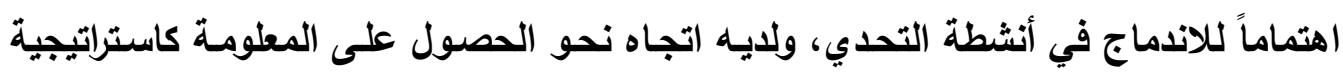

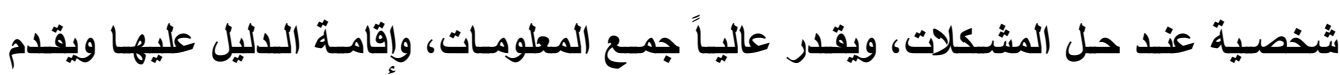

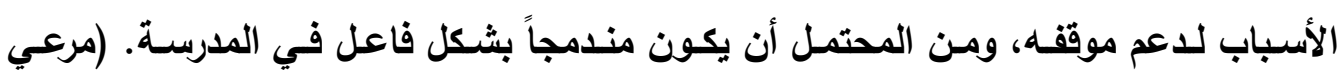

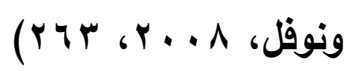




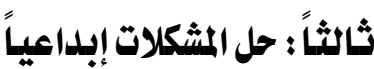

يعرف المتعمون بالقدرة على حل المشكلات إبداعياً من خلال ميلهم وإقبالهم على إلى

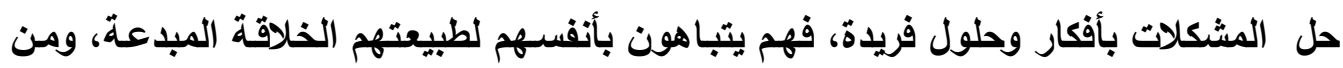
المحتمل أن يظهر إبداعهم من خلال رغبتهم في الانخراط في أنثطة التحدي، مثل الألغاز

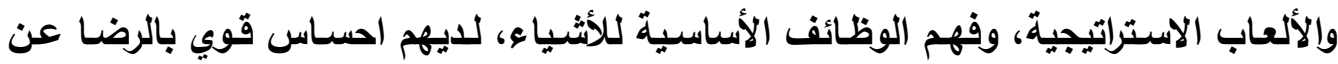

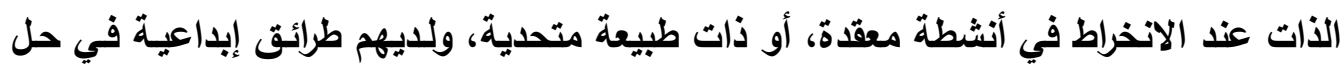

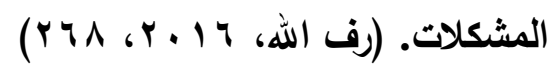
رابعاً : التكامل المعرفي

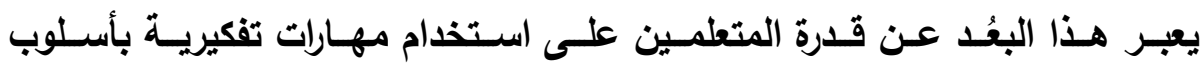

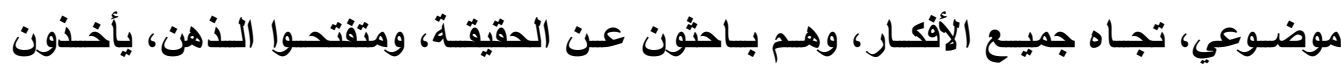

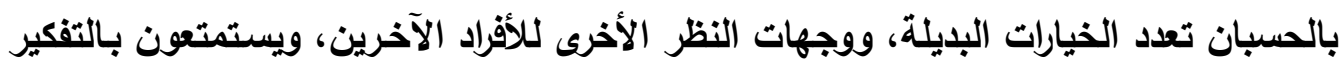

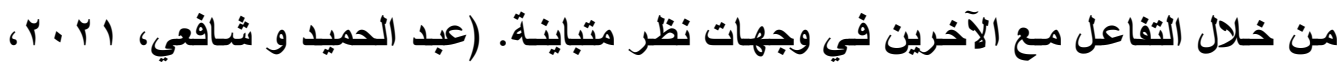
$(0.9$

\section{خصائص الدافعية العقلية}

تتوافر مجموعة مـن الخصائص للاى الأفراد الذين يتميزون بوجود دافعيـة عقليـة

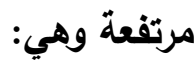
1 - لايهم درجات مرتفعة من الفضول وحب الاستطلاع والذي يمكنهم من القدرة على البحث

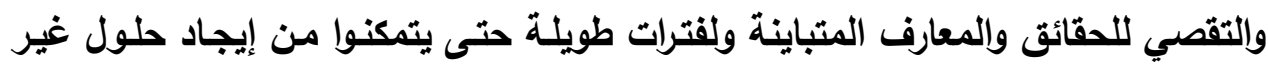
تقليدية للمشكلات والمواقت التي يواجهونها.

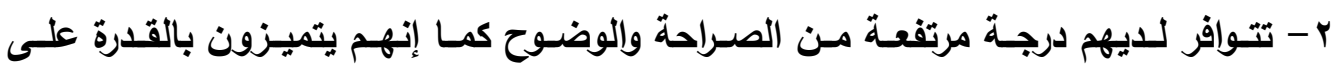

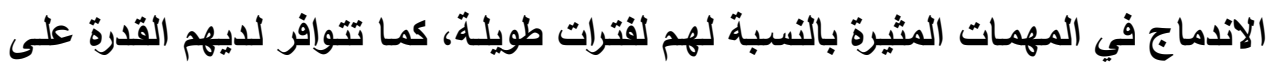
الاندماج في المهمات التعليمية الصعبة والتي تتحدى قدراتهم.

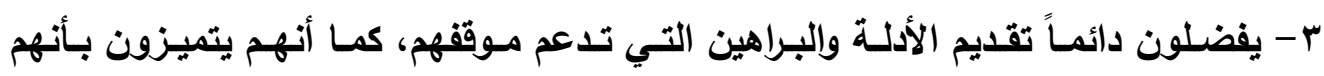
مستمعون جيدون لآراء الآخرين، وعندما يقومون بالنقد فإنهم يقومون بنقد إيجابي قائم

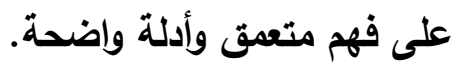


ع - القدرة على المشـاركة الفعالتة في المواقف الاجتماعية والتعليميـة، لمـا يتوافر لهم من اكتساب العديد من المعارف والتي تثكل بنيتهم المعرفية وتسـهم بإعطائهم ثقلاً علمياً عند مواجهة المواقف المختلفة. هـ - يتميزون بأنهم باحثون إيجابيون عن المعرفة والحقيقة، كما أن الأفراد الذين يتميزون

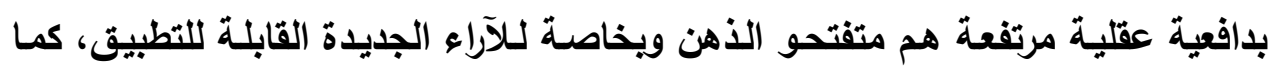

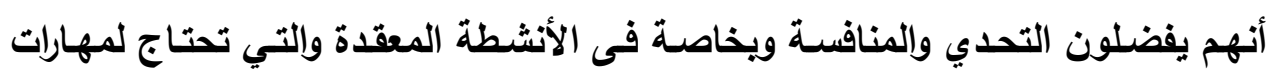

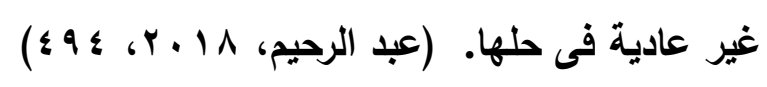

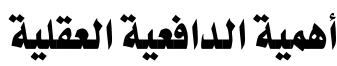

إن الإفعية العقلية تجعل المتطمين مهتمين بالأعمال التي يقومون بها، وتعطي أملاً

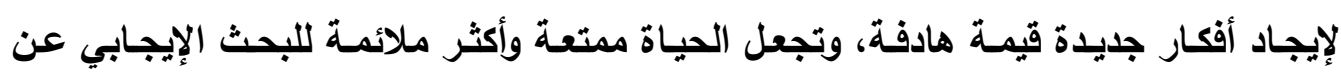

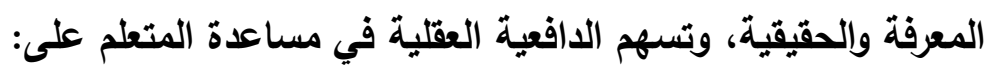

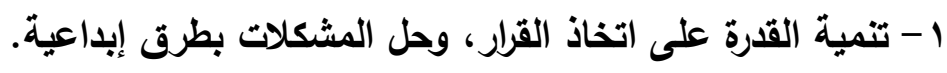

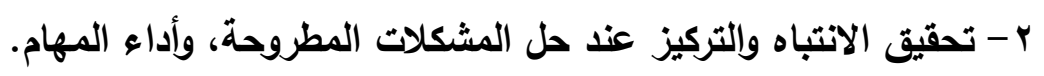

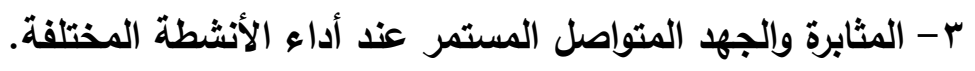

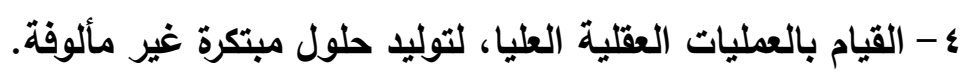

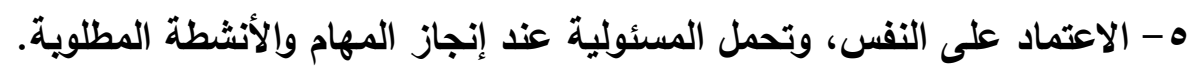

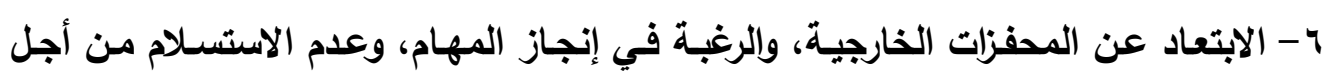
تحقيق الأهداف.

V - تأمين اكتثـاف المعرفة اللازمـة حول أي شـيء، أو أي موضوع معين، ممـا يعزز لايـه

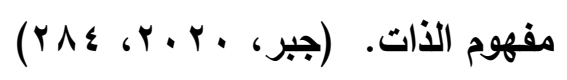

الجودة الشخصية

يعتبر مفهوم الجودة الثخصية عند الإنسان من الموضوعات المههـة ، ويرجع ذلك التكان

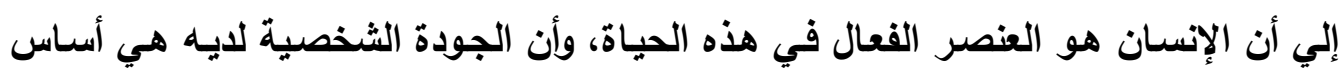
جودة أداءه بالعياة، وقد ظهر مفهوم الجودة الثخصية باللغـة الإنجليزيـة (

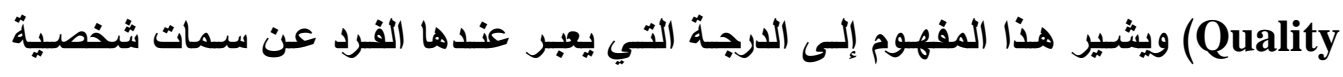

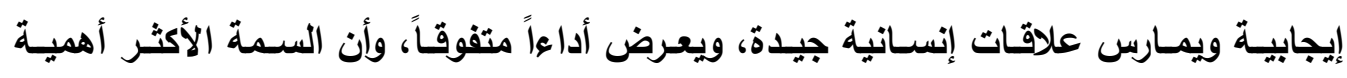


للجودة الشخصية هي (تقدير الذات) باعتبارها من أهم علامات الجودة الشخصية. (المعموري

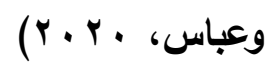
وتعرف الجودة الشخصية بأنها مجموع الصفات التي تتمتع بها الشخصية الإيجابية، وتتضح فى التفكير العالى للأات، والقدرة على ممارسـة المسؤولية الشخصية والمثابرة وتنفيذ بادئ

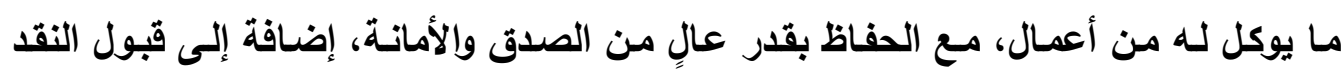

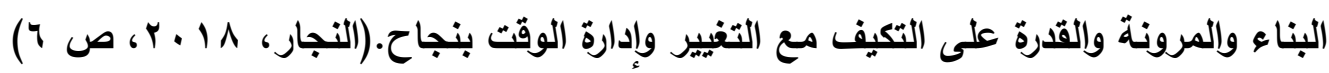
وتعتبر الجودة الثخصية مقياساً للصحة النفسية للفرد وتعد معياراً لنجاح الإنسـان أو فثـله

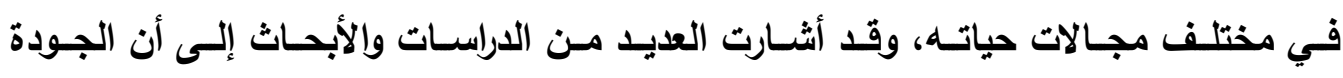

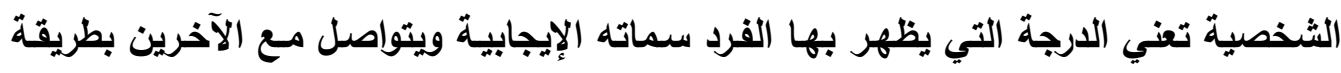

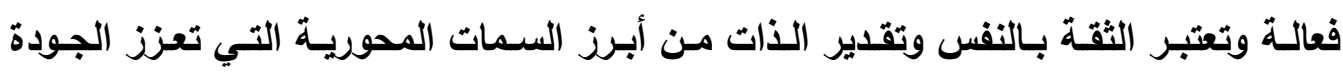
الشخصية.

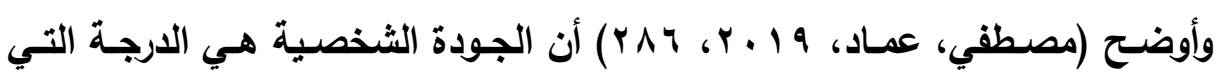
يعبر عندها الفرد عن سمات شخصية إيجابية، ويمارس علاقات إنسانية جيدة ويظهر أداء

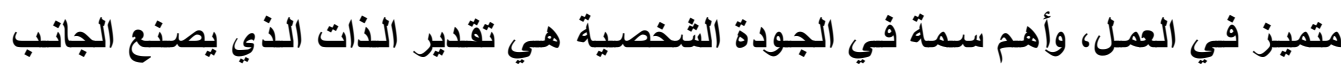

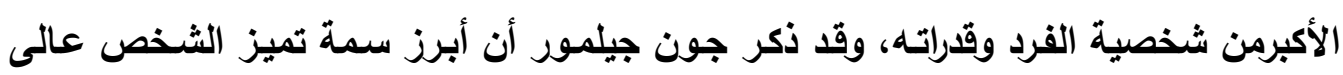
الإنتاج عن غيره هي تقدير الأات. وتمثل الجودة الشخصية أهمية كبيرة حيث تبأ الجودة بالفرد، فالمتفير الأساسي في معادلة الجودة هم الأفراد لأنهم هم الذين يصنعون المنتجات ويبتكرون الخدمات ذات الجودة

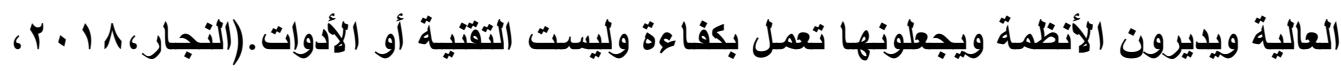

كما تتميز الجـودة الثخصية بأنها لا تتتهي أبـا من التحسين المستمر للذات،

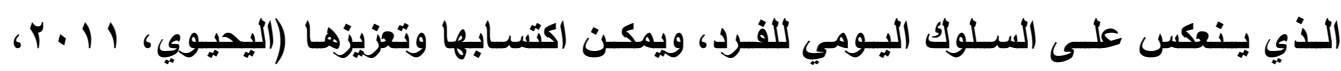
(rv فضـلاً عن أن الجـودة الشخصية والمهنيـة ضـرورية للشباب الذين هم بصدد بـدء مشروعاتهم الأتية، ويصنفها بعض من الباحثين إلى قدرات ومهارات وسمات رئيسية تتفرع

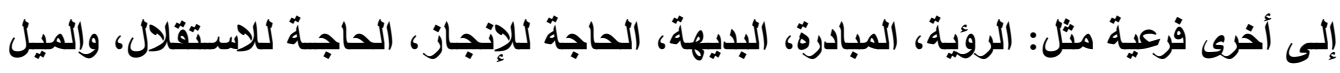


لتحمل قدر معقول من المخاطرة، وتحمل المسؤولية، هذا بالإضـافة إلـى مهارات الاتصـال والثقة بالنفس، والوعي بالذات، والدافعية نحو التعلم بطرق متنوعة، ومهارات الإقتاع، والقدرة

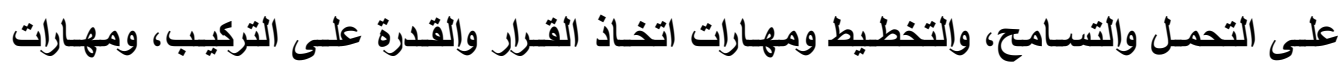
الإصغاء، وجمع المطومات وتحليلها، كنلك مهارات حل المشكلات، وتدوين الملاحظات، وإدارة

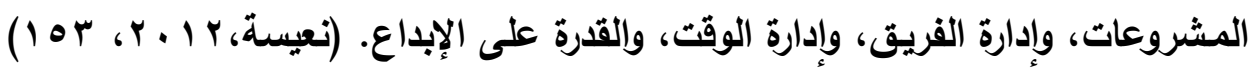

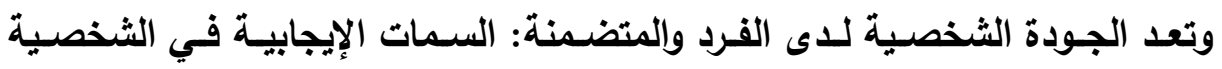

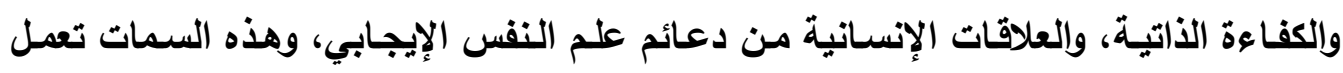

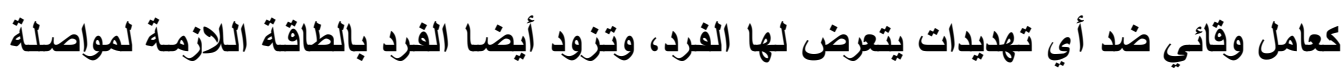

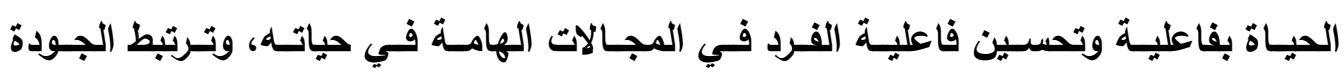

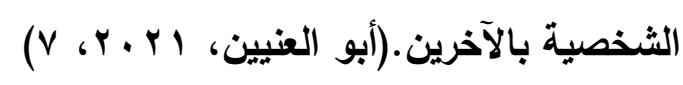
أبعاد الجودة الشخصية تتمثل الجودة الثخصية في ثلاثة أبعاد هي:

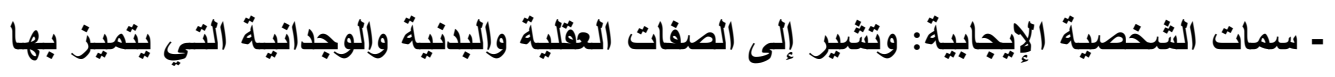

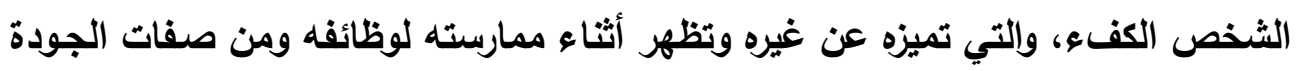

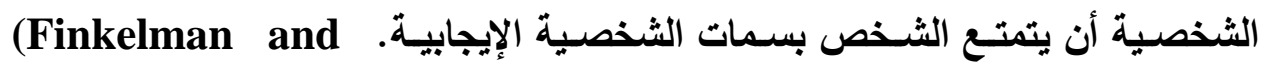
Kenner, 2009) ـ العلاقات الإنسانية: وتثبير إلى التفاعلات الإيجابية التي تحدث بين الفرد والآخرين، والتي

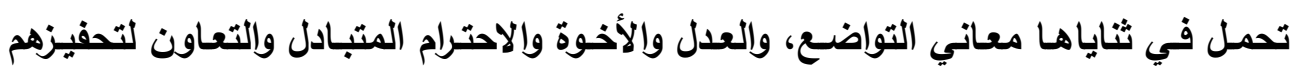

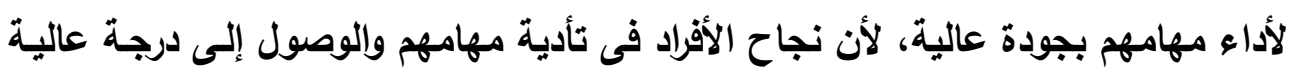

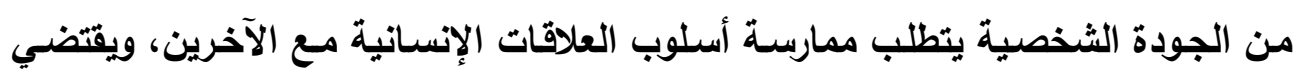

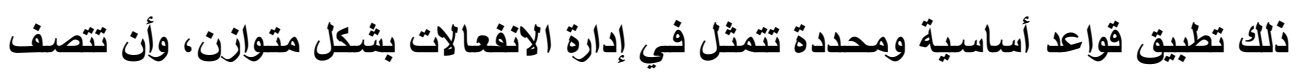

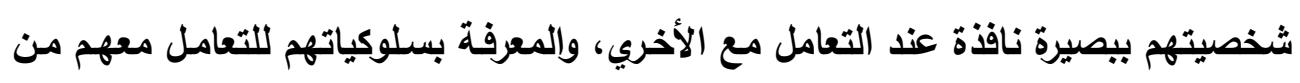

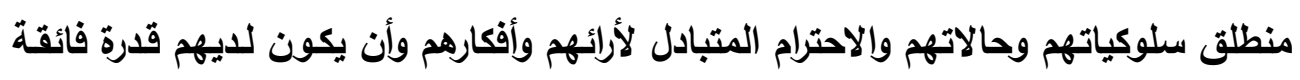

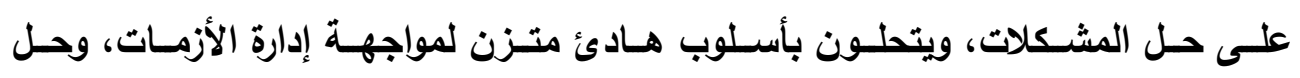

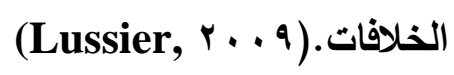


- الأداء الفائق في الدراسـة: يعد أداء العمل بكفاءة وفاعلية من مكونات الجودة الثخصية،

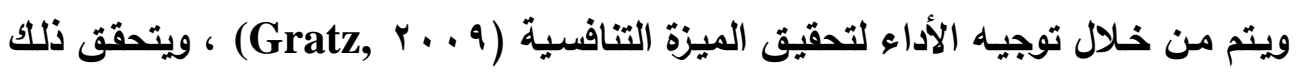

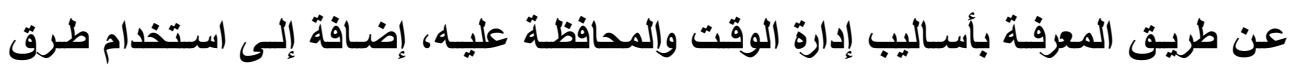

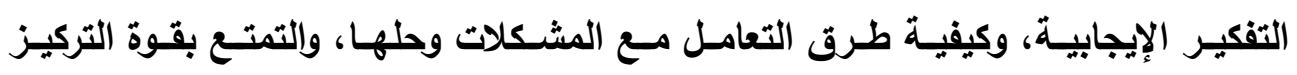

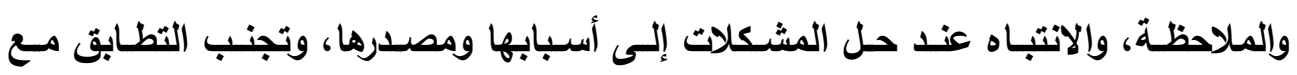

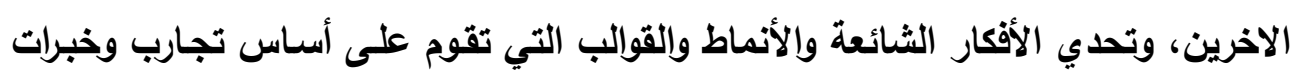
الماضي، والانفتاح على الأفكار والتجاري الجديدة. (Zaffron \&Dave, 2009)

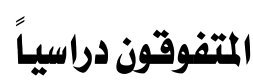
تعتبر الثروة البشرية هي الثروة الحقيقية لأي مجتمع من المجتمعات، ويعد المتفوقون

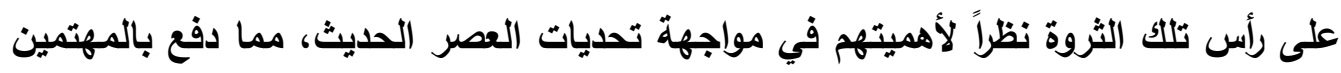
بثؤن علم النفس والتربية بالكثف عن المتفوقين ومن لايهم تفكير ابتكاري، وذلك بهاف رعايتهم والعناية بهم وتحقيق أفضل الوسائل الممكنة لاستثمار تفوقهم.

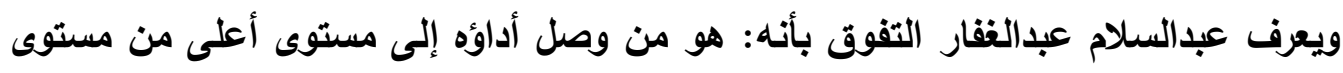

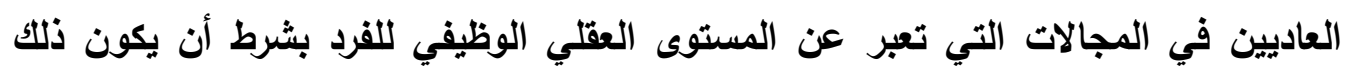
المجال موضع تقدير الجماعة. وهذا التعريف له ثلاثة جوانب:

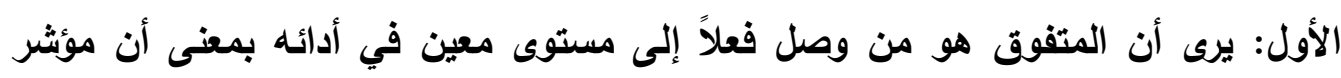
التفوق هو المنجزات الفعلية.

الثاني: أن يكون هذا المستوى أعلى من مستوى العاديين.

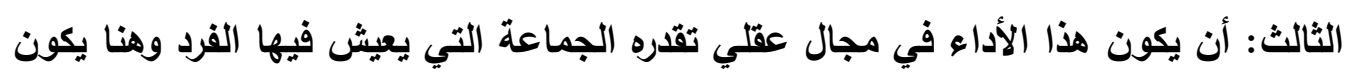

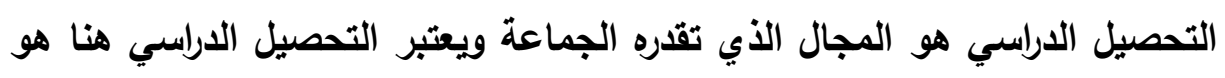

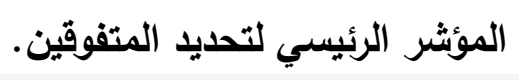

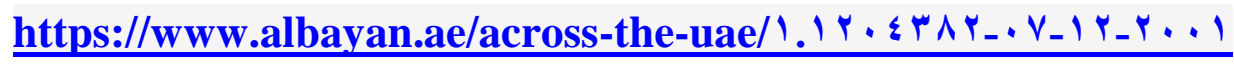

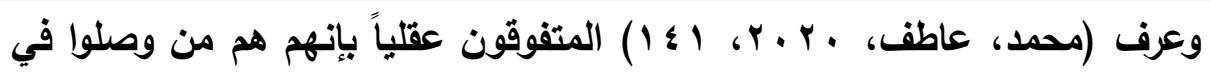

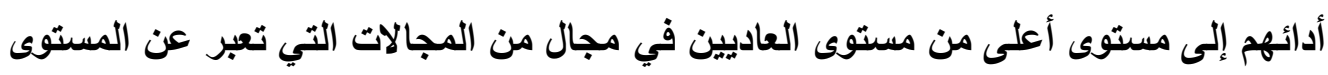
العقلي الوظيفي للفرد بشرط أن يكون المجال موضع تقدير الجماعة. 
وتتكون الموهبة والتفوق من تفاعل (تقاطع) ثلاث مجموعات من السمات الإنسانية، وهي: قدرات عامة فوق المتوسطة، ومستويات مرتفعة من الالتزام بالمهمات (الدافعية)، ومستويات مرتفعة من القدرات الإبداعية (الإبداع). والموهويون والمتفوقون هم أولئك الذين يمتلكون أو لايهم القدرة على تطوير هذه التركيبة من السمات واستخدامها في أي مجال قيم للأداء

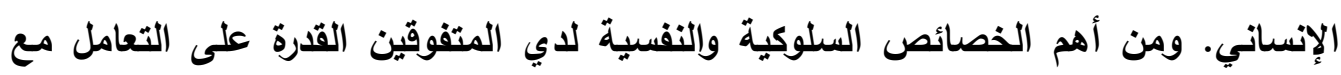
النظم الرمزية والأفكار المجردة، وحب الاستطلاع، وتفضيل العمل الاستقلالى.(الصريي،

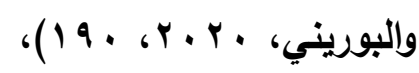

ومن السمات الشخصية التي يمتاز بها الطلبة الموهويون القدرة على ضبط الذات،

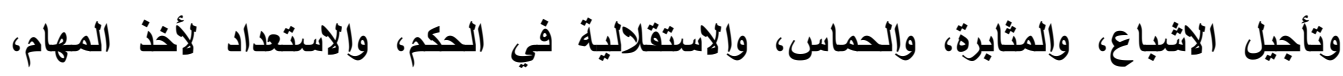

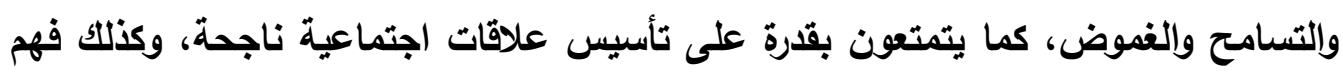
يشعرون بالسعادة والراحة في وجود أصدقائهم، وينفتحون على الآخرين بسهولة، ويمتازئن بوجود قدرة لديهم على توجيه سلوكهم الاجتماعي، ويبدون تفوقا في المواقف التي تحتاج إلى الى

إبداء مستوي واضح من تحمل المسؤولية، ويمكن الاعتماد عليهم. (Davies, 2000 ) إجراءات البجث الميدانية منهج البحث يعد هذا البحث من البحوث الوصفية التي تستهذف تصوير وتحليل خصائص مجموعة معينة، ويصف الظاهرة محل البحث من خلال جمع المعلومات وتصنيفها وتحليلها وكثف العلاقة بين أبعاد متغيراتها المختلفة، والوصول إلى نتائج يمكن تعميمها. أدوات البحث - المقياس كاليفورنيا للافعية العقلية (Factions \& Giancar,1998) مـع إجراء بعض

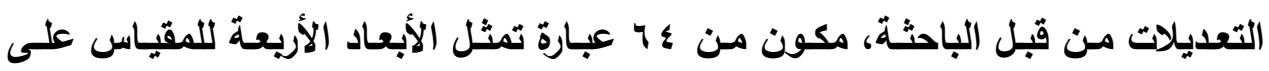

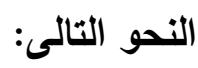




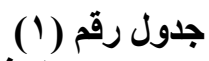

توزيع عبارات مقياس الدافعية العقلية

\begin{tabular}{|c|c|c|c|}
\hline أرقام العبارات & عدد العبارات & الأبعاد & p \\
\hline 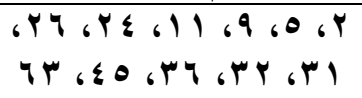 & 11 & التركيز العقلي & .1 \\
\hline 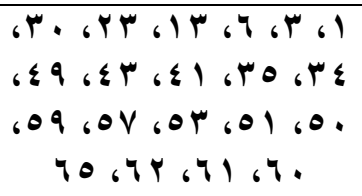 & $r$. & التوجه نحو التعلم &.$r$ \\
\hline 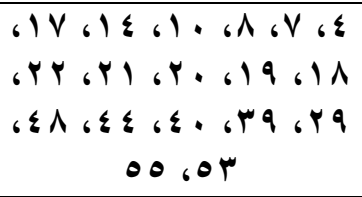 & 11 & حل المشكلات إبداعياً & r \\
\hline 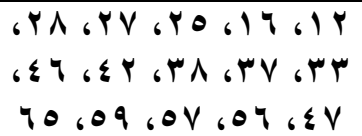 & 10 & التكامل المعرفي &.\{ \\
\hline \multicolumn{2}{|l|}{ § } & \multicolumn{2}{|l|}{ عدد عبارات المقياس } \\
\hline
\end{tabular}

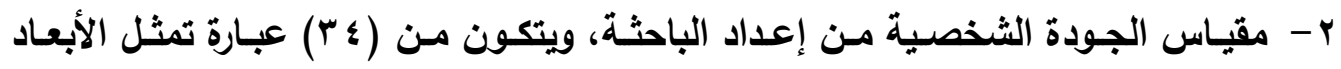
الثلاثة للمقياس على النحو التالى:

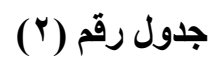

توزيع عبارات مقياس الجودة الثخدية

\begin{tabular}{|c|c|c|c|}
\hline أرقام العبارات & عدد العبارات & الأبعاد & 5 \\
\hline $1 \leq: 1$ & $1 \leqslant$ & سمات الثخصية الإيجابية & .1 \\
\hline$Y Y: 10$ & $\Lambda$ & العلاقات الإنسانية الجيدة &. $\bar{r}$ \\
\hline$r \varepsilon: Y r$ & ir & أداء العمل الفائق &.$r$ \\
\hline \multicolumn{2}{|c|}{ צ r عبارة } & \multicolumn{2}{|l|}{ عدد عبارات المقياس } \\
\hline
\end{tabular}

صدة الأداوات

صدق المحكمين ت تم عرض المقياسين على مجموعة من المختصين في مجال علم النفس

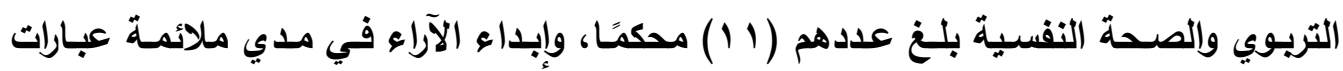

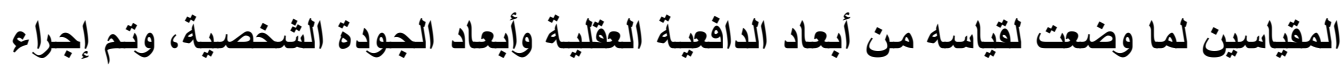
بعض التعديلات وفقاً لأراء السادة المحكمين بما يتناسب مـع موضوع والمرحلة العمريـة لعينة البحث. 
كمـا تـم حسـاب معامـل ارتباط بيرسـون بين الدرجة الكليـة لكل بعُد مـن أبعاد المقياسين مـع الارجة الكلية للمقياس علي النحو التالي:

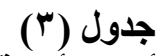

قيم معامل ارتباط بيرسون بين درجات الأبعاد الأربعة والدارجة الكلية لمقياس الدافعية العقلية

\begin{tabular}{|c|c|}
\hline معامل ارتباط البعُد بالدرجة الكلية & أبعاد الدافعية العقلية \\
\hline$\cdot .9 r \wedge$ & التركيز العقلي \\
\hline .947 & التوجه نحو التعلم \\
\hline. $.9 r r$ & حل المشكلات إبداعياً \\
\hline .99. & التكامل المعرفي \\
\hline
\end{tabular}

يتضح من بيانات جدول (r) أن قيم معاملات ارتباط كل بعُد من أبعاد الدافعية

العقلية موجبة ومرتفعة مما يال على قوة الاتساق الداخلي لعبارات كل بعُ من أبعاد

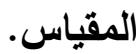

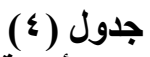

قيم معامل ارتباط بيرسون بين درجات الأبعاد الأربعة و الدرجة الكلية لمقياس الجودة الثخصية

\begin{tabular}{|c|c|}
\hline معامل ارتباط البعُد بالدرجة الكلية & أبعاد الجودة الشخصية \\
\hline$\cdot .9 \wedge r$ & سمات الثخصية الإيجابية \\
\hline $.9 \vee r$ & العلاقات الإنسانية الجيدة \\
\hline .970 & أداء العمل الفائق \\
\hline
\end{tabular}

يتضـح مـن بيانـات جدول (؛) أن قيم معاملات ارتبـاط كل بعُد من أبعـاد الجودة الشخصية موجبـة ومرتفعة ممـا يـل على قوة الاتسـاق الـاخلي لعبارات كل بعُد من أبعاد المقياس.

\section{ثبات الأدوات}

قامت الباحثة بالتحقق من ثبات المقياسين عن طريق تطبيق المقياسين على عينة

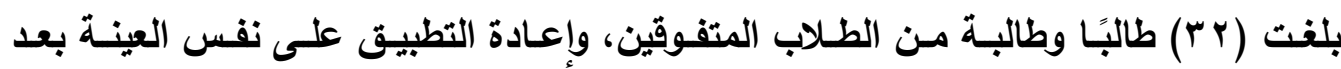
أسبوعين من التطبيق الأول، وتم التأكد من ثبات الدرجة الكلية والأبعاد للمقياسين بحساب المتوسط الحسـابي العام والانحراف المعياري لكل من التطبيق الأول والثاني، وحسـاب قيمـة معامل الثبات بطريقة الاتساق الاخلي وفقاً لمعادلة كرونباخ ألفا، على النحو التالى: 


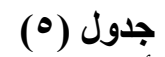

معاملات الثبات لأبعاد مقياس الدافعية العقلية

\begin{tabular}{|c|c|}
\hline معامل الثبات & أبعاد مقياس الدافعية العقلية \\
\hline .940 & التركيز العقلى \\
\hline .979 & التوجه نحو التعلّم \\
\hline .909 & حل المشكلات إبداعياً \\
\hline $.9 \vee 7$ & التكامل المعرفي \\
\hline
\end{tabular}

يتضـح من جدول (0) ارتفاع قيم معامل الثبات لكل بعُد من أبعاد مقياس الدافعية العقلية،

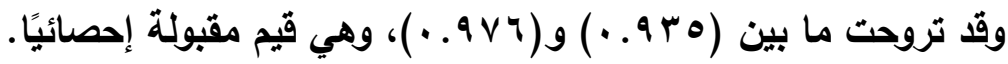

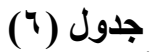

معاملات الثبات لأبعاد مقياس الجودة الثخصية

\begin{tabular}{|c|c|}
\hline معامل الثبات & أبعاد مقياس الجودة الثخصية \\
\hline .911 & سمات الثخصية الإيجابية \\
\hline .910 & العلاقات الإنسانية الجيدة \\
\hline$\cdot .9 \wedge r$ & أداء العمل الفائق \\
\hline
\end{tabular}

يتضـح مـن جدول (†) معـاملات ثبـات أبعـاد الجـودة الشخصية مرتفعة، وهـي قيم مقبولة إحصائيًا ومن الجدولين (0) و(†) يتضـح أن المقياسين على درجة عاليـة من الثبات تؤكد

صلاحيتهما للتطبيق. عينة البحث الميداذي طبق البحث على عينة قوامها (Y V طالبَّا من الطلاب الحاصلين على الثـهادة الإعداديـة بمجمـوع ه 9\% فـأكثر، والمتقدمين للالتحساق بمــارس المتفـوقين للعـام الدراسـي

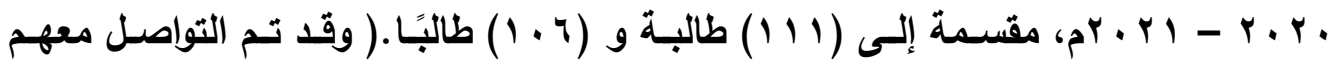

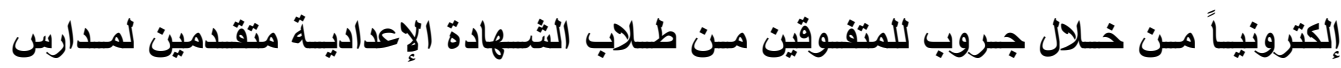




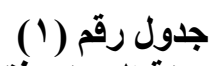

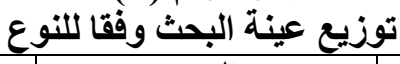

\begin{tabular}{|c|c|c|}
\hline النسبة & العدد & النوع \\
\hline$\% 01 . r$ & 111 & إناث \\
\hline$\% \leqslant \wedge . \wedge$ & 1.7 & ذكور \\
\hline$\% 1 \ldots$ & YIV & الإجمبالى \\
\hline
\end{tabular}

\section{الأساليب الإحصائية المستخدمة لمعالجة البيانات}

- بعد تطبيق المقياسين وتفريغهما في جداول لحصر التكرارات تم استخدام برنـامج اكسل

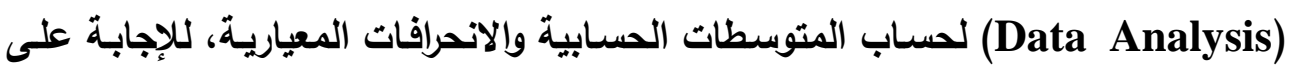

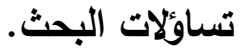

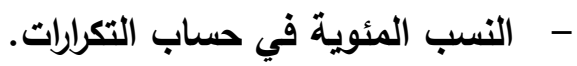

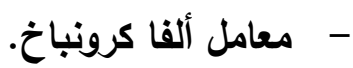

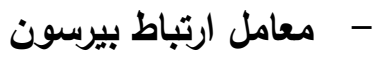
- - اختبار Z لدراسة الاختلاف بين الأكور والإناث في أبعاد مقياسي الدافعية العقلية والجودة الشخصية.

\section{نتائج البحث ومناقشثتها}

1 - النتائج الخاصـة بـالفرض الأول: الذي ينص على: " توجد علاقة ارتباطية موجبة دالـة

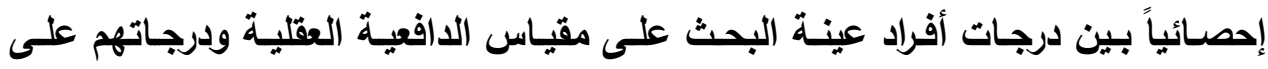

مقياس الجودة الشخصية.

وللتحقق من هذا الفرض تم حساب معامل ارتباط بيرسون بين درجات الأكور والإناث علي مقياس الدافعية العقلية ومقياس الجودة الشخصية على النحو التالى: (v) جدول

معامل ارتباط بيرسون لاراسة العلاقة بين الدافعية العقلية والجودة الثخصية لأفراد العينة من الإناث

\begin{tabular}{|c|c|c|}
\hline \multicolumn{3}{|c|}{$(111=0)$} \\
\hline مستوي الدلالة & معامل الارتباط & \\
\hline \multirow{2}{*}{ دال إحصائياً } & \multirow{2}{*}{0.905} & الدافعية العقلية \\
\hline & & الجودة الشخصية \\
\hline
\end{tabular}

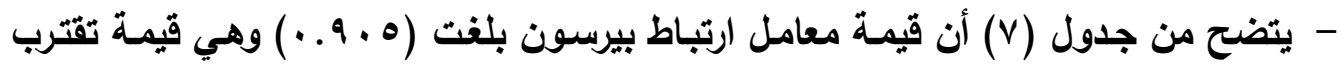
من (+1) مما يدل على وجود علاقة ارتباطية موجبة قوية بين أبعاد كل من مقياس الدافعية

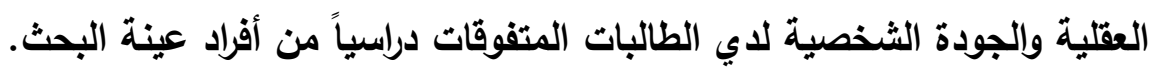




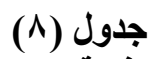

معامل ارتباط بيرسون لاراسة العلاقة بين الدافعية العقلية والجودة الثخصية لأفراد العينة من الذكور

\begin{tabular}{|c|c|c|}
\hline \multicolumn{3}{|c|}{$(1 \cdot 7=0)$} \\
\hline مستوي الدلالة & معامل الارتباط & \\
\hline \multirow{2}{*}{ دال إحصائياً } & \multirow{2}{*}{0.879} & الدافعية العقلية \\
\hline & & الجودة الثخصية \\
\hline
\end{tabular}

- يتضح من جدول (^) أن قيمة معامل ارتباط بيرسون بلغت (Av9 . . ) وهي قيمة موجبة

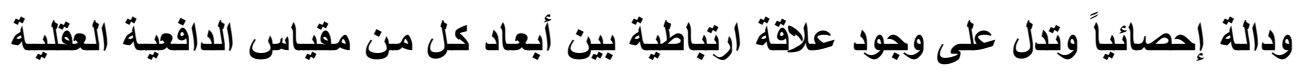

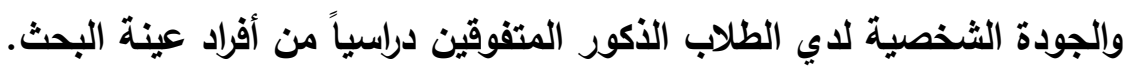
ومن الجدولين (V) و(^) السابقين يتحقق الفرض الأول القائل " توجد علاقة ارتباطية

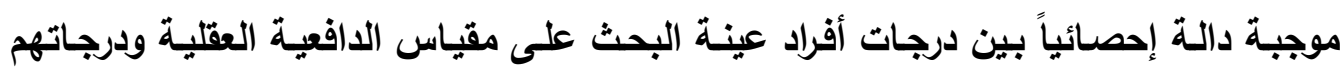
على مقياس الجودة الشخصية ". r- النتائج الخاصـة بـالفرض الثاني الذي ينص على: " لا توجد فروق دانئه دالـة إحصائياً بين

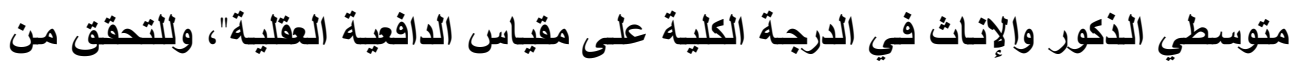
صحة هذا الفرض تم حساب المتوسطات الحسابية والانحرافات المعياريـة لاستجابات أفراد

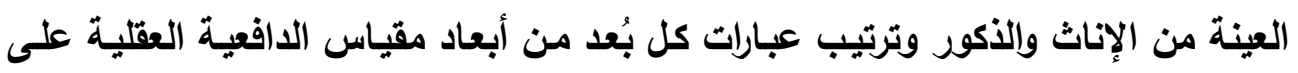
النحو التالي: n n 


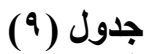

المتوسطات الحسابية والانحرافات المعيارية لدرجات استجابات أفراد العينة الخاصة بيُعد التركيز

\begin{tabular}{|c|c|c|c|c|c|c|c|}
\hline \multicolumn{8}{|c|}{ ل } \\
\hline \multirow[b]{2}{*}{ الترتيب } & \multicolumn{2}{|c|}{ الذكور } & \multirow[b]{2}{*}{ الترتيب } & \multicolumn{2}{|c|}{ الإناث } & \multirow[b]{2}{*}{ العبارات } & \multirow{2}{*}{ 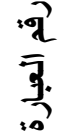 } \\
\hline & الانحراف & المستوسطي & & الالمعراف & الحستوسطي & & \\
\hline$\wedge$ & 45.83 & 1.33 & $\wedge$ & 41.57 & 1.72 & من الانتياه بسي أتوقة. & r \\
\hline 0 & 38.16 & 2.01 & 0 & 42.72 & 2.09 & أكره التعامل مع أي & 0 \\
\hline$v$ & 43.98 & 1.50 & 9 & 45.19 & 1.54 & كمبيوترية جلئليدة & 9 \\
\hline 1 & 45.53 & 2.67 & 1 & 45.96 & 2.46 & يستغرق حل بعضاً وقلاً & 11 \\
\hline 7 & 45.75 & 1.67 & 7 & 46.09 & 1.92 & أتحكيز لأفكاري دون & $r \varepsilon$ \\
\hline$\varepsilon$ & 48.72 & 2.08 & r & 43.41 & 2.38 & أجد صعوفية أحين تكمنا في & Y \\
\hline r & 43.55 & 2.49 & $r$ & 47.17 & 2.36 & لالاسئلة السهئة التي مني & ו \\
\hline$v$ & 43.98 & 1.50 & $\wedge$ & 41.57 & 1.72 & أضرار الإلتترنت أكثر & rr \\
\hline$v$ & 43.98 & 1.50 & 1. & 48.47 & 1.45 & 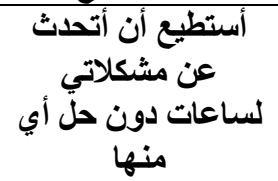 & T \\
\hline 7 & 45.75 & 1.67 & v & 41.55 & 1.82 & أعاني من مشكيلات أداء & $\leqslant 0$ \\
\hline$r$ & 50.33 & 2.17 & $\varepsilon$ & 41.45 & 2.18 & أجد صعوبة في اتخاذ & r \\
\hline - & $\leq 0.0$ & 1.87 & - & ะ..1. & 1.97 & المتوسط العام & \\
\hline
\end{tabular}

- يشير جدول (9) إلى متوسطات استجابات أفراد العينة من الذاءكور والإناث على بُعد التركيز

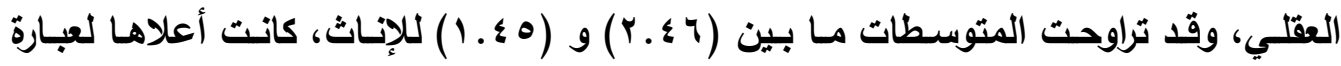
(يستغرق حل بعض المشكلات وقتاً طويلاً)، وأدناها لعبارة (أستطيع أن أتحدث عن مشكلاتي لساعات دون حل أي منها). 


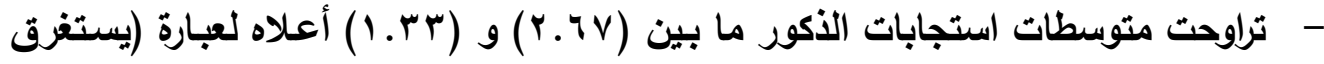
حل بعض المشكلات وقتاً طويلاً.)، وأدناهـا لعبارة (مشكلتي أنسي أتوقف عن الانتباه

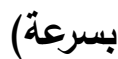
- ـ يستغرق حل بعض المشكلات وقتاً طويلاً لاي كل من الإناث والذكور من أفراد العينة من المتفوقين دراسياً. حيث حصلت العبارة على الترتيب الأول لمتوسطات استجابات كل منهم

$$
\text { على بُعد التركيز العقلي. }
$$

- - كما يتضح من الجدول السابق أن قيمة المتوسط العام لاستجابات أفراد العينة من الإناث

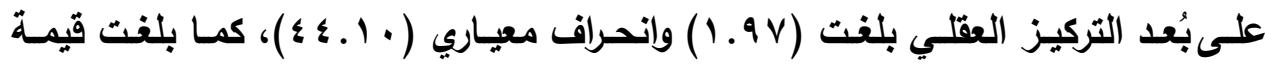

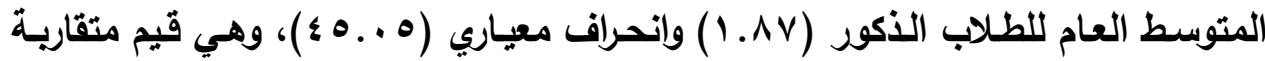
تلل على عدم وجود فروق بين الإناث والذكور في متوسطات درجات استجابتهم على بُعد التركيز العقلي.

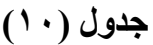

المتوسطات الحسابية والانحر افات المعيارية لارجات استجابات أفراد العينة الخاصة بيُعد التوجه نحو التعلم

\begin{tabular}{|c|c|c|c|c|c|c|c|}
\hline \multirow[b]{2}{*}{ الترتيب } & \multicolumn{2}{|c|}{ الأكور } & \multirow[b]{2}{*}{ الترتيب } & \multicolumn{2}{|c|}{ الإناث } & \multirow[b]{2}{*}{ العبارات } & \multirow{2}{*}{ 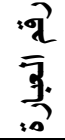 } \\
\hline & المعياري & المسابي & & المعياري & الحستبي & & \\
\hline 1 & $\mathbf{5 7 . 5 2}$ & 3.00 & $\wedge$ & 43.41 & 2.38 & أنطلع دائما لتعلم الأشياء & 1 \\
\hline 1 & 57.52 & 3.00 & $r$ & 52.20 & 2.82 & أحب الألغاز & $r$ \\
\hline 1 & 57.52 & 3.00 & $\varepsilon$ & 48.20 & 2.64 & دائما متشوق للتُطلم عن المختفة. & 7 \\
\hline r & 50.20 & 2.83 & r & 52.20 & 2.82 & 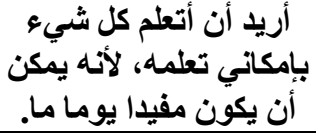 & ir \\
\hline 1 & $\mathbf{5 7 . 5 2}$ & 3.00 & 1 & 55.93 & 2.91 & 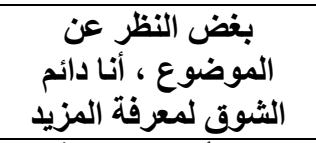 & rT \\
\hline 7 & 45.60 & 2.33 & 11 & 40.84 & 2.19 & دائما أكمل عملي في & $r$. \\
\hline 1 & 57.52 & 3.00 & r & 52.20 & 2.82 & أجدا أن الإنترنت أداة & ץ \\
\hline$\varepsilon$ & 45.53 & 2.67 & 1. & 43.83 & 2.27 & من السهل على تنظيم & ro \\
\hline 1 & 57.52 & 3.00 & 1 & 55.93 & 2.91 & أحب تعلم أشياء جديدة & $\leqslant 1$ \\
\hline$\varepsilon$ & 45.53 & 2.67 & $r$ & 49.21 & 2.73 & عمل الأشياء كالكمبيوتر المزيد عن & $\varepsilon r$ \\
\hline
\end{tabular}




\begin{tabular}{|c|c|c|c|c|c|c|c|}
\hline \multirow[b]{2}{*}{ الترتيب } & \multicolumn{2}{|c|}{ الأكور } & \multirow[b]{2}{*}{ الترتيب } & \multicolumn{2}{|c|}{ الإناث } & \multirow[b]{2}{*}{ العبار ات } & \multirow{2}{*}{$\frac{39}{3}$} \\
\hline & الانحراف & الحستوسط الحسب & & الانحر افياري & المستوسط الحسبي & & \\
\hline & & & & & & والهواتف الذكية وغيرها & \\
\hline 0 & 43.55 & 2.49 & 9 & 42.68 & 2.28 & أفضل أن اكتشف وأتعلم & $\leqslant 9$ \\
\hline 1 & $\mathbf{5 7 . 5 2}$ & 3.00 & $r$ & 52.20 & 2.82 & 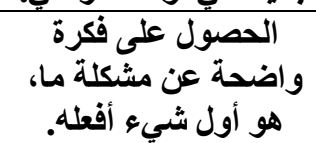 & 0 . \\
\hline 1 & $\mathbf{5 7 . 5 2}$ & 3.00 & 0 & 47.10 & 2.64 & نشاط يتسم بإنتحدي أختار عن أنتار & 01 \\
\hline 7 & 45.60 & 2.33 & $\Lambda$ & 43.41 & 2.38 & 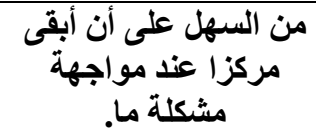 & or \\
\hline 1 & $\mathbf{5 7 . 5 2}$ & 3.00 & 7 & 48.22 & 2.55 & 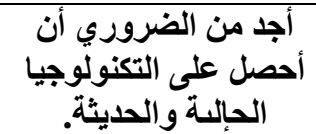 & ov \\
\hline 1 & $\mathbf{5 7 . 5 2}$ & 3.00 & ir & 60.61 & 1.00 & 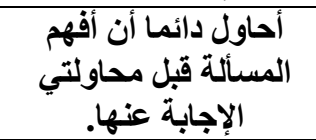 & ०q \\
\hline 1 & $\mathbf{5 7 . 5 2}$ & 3.00 & $\bullet$ & 47.10 & 2.64 & تعلم أشياء جديدة يجعل ممتعة. & 7. \\
\hline$r$ & 50.20 & 2.83 & 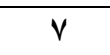 & 45.94 & 2.54 & أحافظ على عملي منظما. & 71 \\
\hline 1 & $\mathbf{5 7 . 5 2}$ & 3.00 & r & 52.20 & 2.82 & 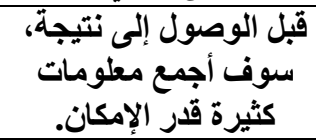 & Tr \\
\hline 1 & $\mathbf{5 7 . 5 2}$ & 3.00 & 9 & 42.68 & 2.28 & المشعلات من مشكلاتة الستلّة & 70 \\
\hline- & or.v. & 2.86 & - & $\varepsilon \wedge . \wedge 1$ & 2.52 & المتوسط العام & \\
\hline
\end{tabular}

يشير جدول ( • 1) إلى متوسطات استجابات أفراد العينة من الأكور والإنـاث على بُعد التوجها.

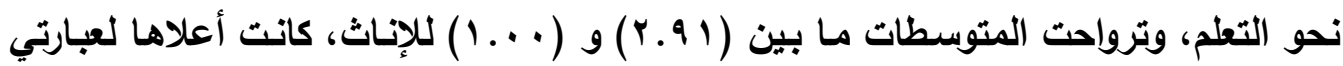
(بغض النظر عن الموضوع أنا دائم الثوق لمعرفة المزيد - أحب تعلم أثياء جديدة)، وأدناها لعبارة (دائما أكمل عملي في الوقت المحدد).

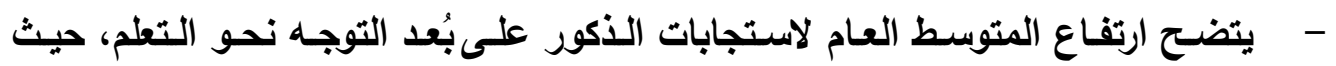

$$
\text { تراوحت متوسطات ما بين ( . ..r) و (r.r.r). }
$$


- كما يتضح من الجدول السابق أن قيمة المتوسط العام لاستجابات أفراد العينة من الإناث

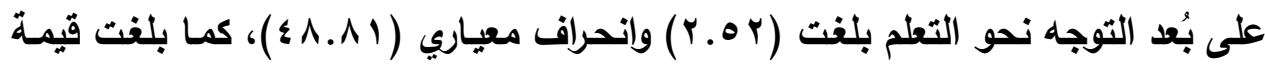

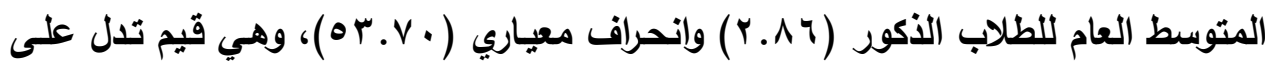
وجود فروق بين الإناث والذكور في متوسطات درجات استجابتهم على بُعد التوجهـ نحو

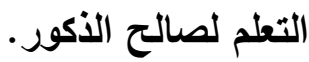

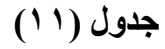

المتوسطات الحسابية والاتحرافات المعيارية لارجات استجابات أفراد العينة الخاصة بيُعد حل المشكلات إبداعياً

\begin{tabular}{|c|c|c|c|c|c|c|c|}
\hline \multirow[b]{2}{*}{ الترتيب } & \multicolumn{2}{|c|}{ الأكور } & \multirow[b]{2}{*}{ الترتيب } & \multicolumn{2}{|c|}{ الإناث } & \multirow[b]{2}{*}{ العبارات } & \multirow{2}{*}{ : } \\
\hline & الانحراف & الحستوسطي & & الالمعراف & المستوسط & & \\
\hline$r$ & 45.53 & 2.67 & $r$ & 51.74 & 2.73 & أستمتع في البحكث عن & $\varepsilon$ \\
\hline$\varepsilon$ & 43.75 & 2.50 & $\wedge$ & 47.17 & 2.36 & لاي مهارة في توقع & v \\
\hline 1 & $\mathbf{5 7 . 5 2}$ & 3.00 & v & 43.79 & 2.46 & فهم المستعائل المعقداة. & $\wedge$ \\
\hline$\varepsilon$ & 43.75 & 2.50 & 1. & 43.83 & 2.27 & المتيلة وضكع الخطية حل & 1. \\
\hline 7 & $\mathbf{5 7 . 6 9}$ & 2.00 & v & 43.79 & 2.46 & 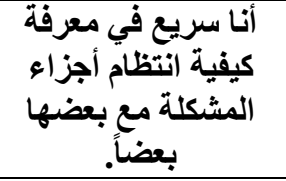 & $1 \varepsilon$ \\
\hline$r$ & 45.53 & 2.67 & 0 & 45.50 & 2.55 & أستطيع أن آتي بحل & IV \\
\hline$r$ & $\mathbf{5 0 . 2 0}$ & 2.83 & 7 & 45.96 & 2.46 & 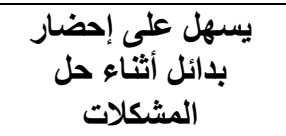 & 11 \\
\hline$r$ & 45.53 & 2.67 & 0 & 45.50 & 2.55 & 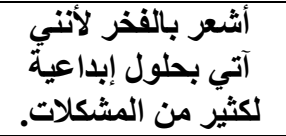 & 19 \\
\hline$\varepsilon$ & 43.75 & 2.50 & 9 & 49.31 & 2.27 & 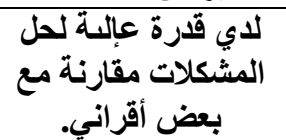 & $r$. \\
\hline$\varepsilon$ & 43.75 & 2.50 & v & 43.79 & 2.46 & 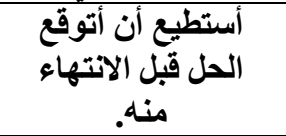 & Y \\
\hline$r$ & 45.53 & 2.67 & V & 43.79 & 2.46 & أنفوق في العصف & YY \\
\hline
\end{tabular}




\begin{tabular}{|c|c|c|c|c|c|c|c|}
\hline \multirow[b]{2}{*}{ الترتيب } & \multicolumn{2}{|c|}{ الأكور } & \multirow[b]{2}{*}{ الترتيب } & \multicolumn{2}{|c|}{ الإناث } & \multirow[b]{2}{*}{ العبارات } & \multirow{2}{*}{$\frac{.9}{3}$} \\
\hline & الانحرافي & المتوسطي الحسبي & & الانحرافي & الحسبابي المتوسط & & \\
\hline & & & & & & الذهني للتوليد حلات & \\
\hline 1 & $\mathbf{5 7 . 5 2}$ & 3.00 & $r$ & 51.74 & 2.73 & أستشيع مما أن أتعلم أكثر الآن & rq \\
\hline$r$ & 50.20 & 2.83 & $\varepsilon$ & 49.21 & 2.73 & في حل مثل ألكلة أكلة، أتخيل & $r q$ \\
\hline$\bullet$ & 43.55 & 2.49 & v & 43.79 & 2.46 & 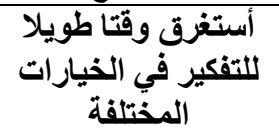 & $\varepsilon$. \\
\hline$r$ & 45.53 & 2.67 & $\varepsilon$ & 49.21 & 2.73 & آلتي غالبا بحلول تشسم & $\leq \varepsilon$ \\
\hline$\varepsilon$ & 43.75 & 2.50 & 1 & 55.93 & 2.91 & 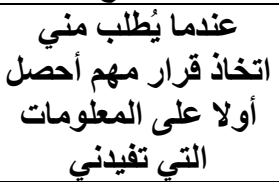 & $\varepsilon \wedge$ \\
\hline 7 & 57.69 & 2.00 & 11 & 41.45 & 2.18 & الألغاز التيع حل أواجها. & or \\
\hline$r$ & 50.20 & 2.83 & $r$ & 51.74 & 2.91 & كيف تعمل بمحاولة فأشياء & 00 \\
\hline- & $\varepsilon \wedge . q^{2}$ & 2.60 & - & $\varepsilon V . r$. & 2.54 & المتوسط العام & \\
\hline
\end{tabular}

- يشير جدول (11) إلى متوسطات استجابات أفراد العينة من الذكور والإناث على بُعد حل

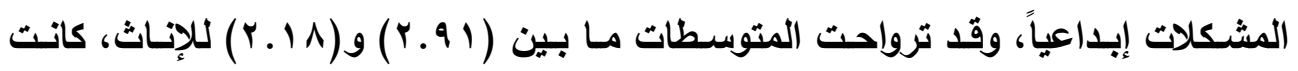
أعلاها لعبارة (عندما يُطلب مني اتخاذ قرار مهم أحصل أولا على المعلومات التي تفيدني)، وأدناها لعبارة (أستطيع حل معظم الألغاز التي أواجهها.).

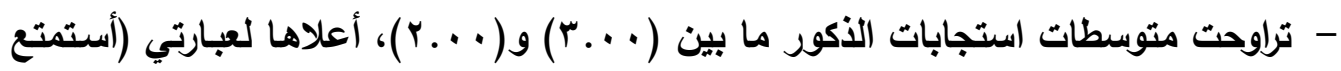

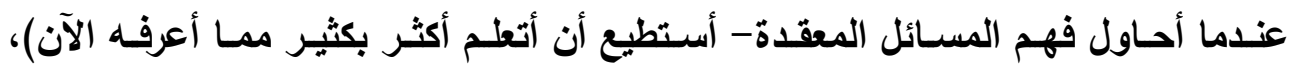

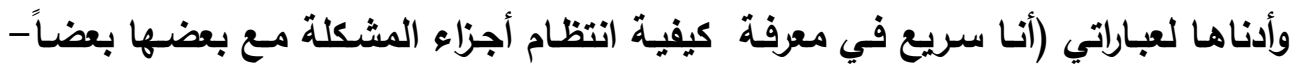
أستطيع حل معظم الألغاز التي أواجهها). - كما يتضح من الجدول السابق أن قيمة المتوسط العام لاستجابات أفراد العينة من الإناث

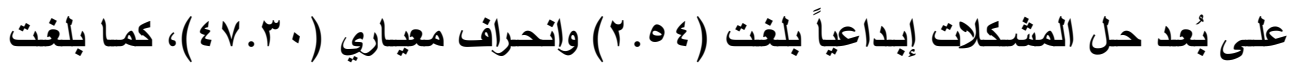




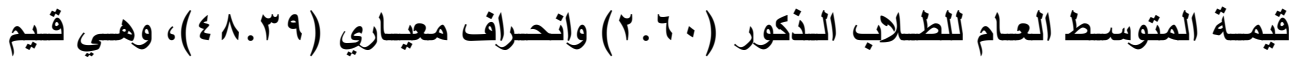
متقارية تدل على عدم وجود فروق بين الإناث والذكور في متوسطات درجات استجابتهم على بُعد حل المشكلات إبداعياً.

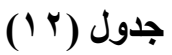

المتوسطات الحسابية والانحر افات المعيارية لدرجات استجابات أفراد العينة الخاصة بيُعد التكامل

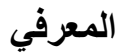

\begin{tabular}{|c|c|c|c|c|c|c|c|}
\hline \multirow[b]{2}{*}{ الترتيب } & \multicolumn{2}{|c|}{ الذكور } & \multirow[b]{2}{*}{ الترتيب } & \multicolumn{2}{|c|}{ الإناث } & \multirow[b]{2}{*}{ العبارات } & :ฮิ \\
\hline & المعياري & الحسابي & & المعياري & الحستوسطي & & $\underset{8}{3}$ \\
\hline$\varepsilon$ & 40.08 & 2.16 & r & 45.50 & 2.55 & 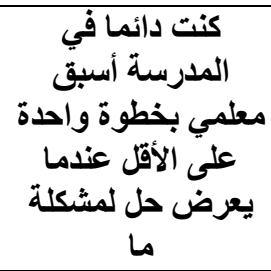 & ir \\
\hline 1. & 50.53 & 1.17 & Ir & 52.53 & 1.18 & معلومات تكنولوجيا & 17 \\
\hline$r$ & 40.03 & 2.33 & $\varepsilon$ & 47.17 & 2.36 & الآخرون يعني أنتكير التفكير لاه & ro \\
\hline r & 43.55 & 2.49 & $r$ & 42.65 & 2.37 & دائما استتمتع بمتابعة & $r v$ \\
\hline 0 & 38.16 & 2.01 & v & 41.55 & 1.82 & 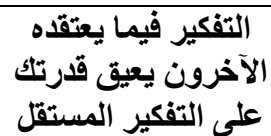 & r^ \\
\hline 1 & 57.52 & 3.00 & 1 & 49.21 & 2.73 & 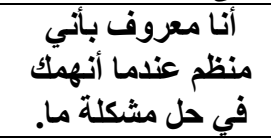 & rr \\
\hline$\wedge$ & 40.16 & 1.83 & 11 & 45.19 & 1.54 & نظر الآخريَت مضيعة وجهات & $r v$ \\
\hline v & 50.40 & 1.83 & 9 & 43.97 & 1.73 & 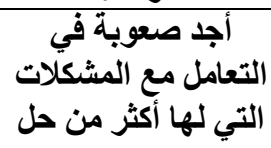 & rs \\
\hline 9 & 45.83 & 1.33 & 11 & 45.19 & 1.54 & ليس مهي محاولة الاستمرار & $\varepsilon r$ \\
\hline
\end{tabular}




\begin{tabular}{|c|c|c|c|c|c|c|c|}
\hline \multirow[b]{2}{*}{ الترتيب } & \multicolumn{2}{|c|}{ الأكور } & \multirow[b]{2}{*}{ الترتيب } & \multicolumn{2}{|c|}{ الإناث } & \multirow[b]{2}{*}{ العبارات } & \multirow{2}{*}{ 3. } \\
\hline & الانحراف المعياري & المتوسطي & & الانحراف & المستوسطي & & \\
\hline$\varepsilon$ & 40.08 & 2.16 & 11 & 45.19 & 1.54 & 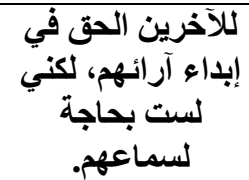 & $\varepsilon 7$ \\
\hline 11 & 57.87 & 1.00 & $\wedge$ & 40.94 & 1.81 & 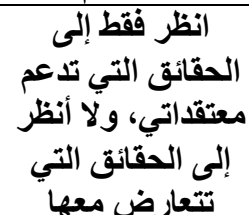 & $\leqslant V$ \\
\hline 11 & 57.87 & 1.00 & 1. & 47.33 & 1.64 & 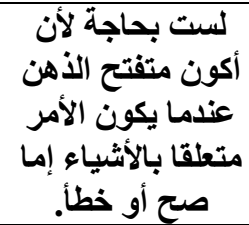 & 07 \\
\hline 9 & 45.83 & 1.33 & 9 & 43.97 & 1.73 & 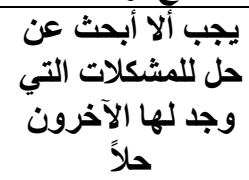 & $\Delta V$ \\
\hline r & 43.55 & 2.49 & 7 & 42.77 & 1.91 & 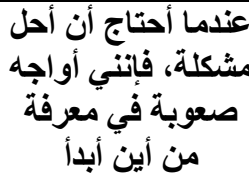 & 09 \\
\hline 7 & 40.16 & 1.84 & $\bullet$ & 42.72 & 2.09 & 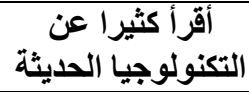 & 70 \\
\hline- & $\leq 7.11$ & 1.86 & - & $\leqslant 0.9$ & 1.90 & لمتوسط العام & \\
\hline
\end{tabular}

- يشير جدول (r I إلى متوسطات استجابات أفراد العينة من الذكور والإنـاث على بُعد

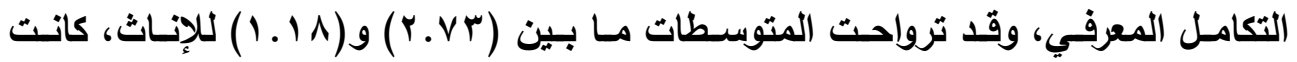
أعلاهـا لعبارة (أنـا معروف بأني منظم عندما أنهمك في حل مشكلة مـا)، وأدناهـا لعبارة (يزعجني تعلم معلومات تكنولوجيا جليدة).

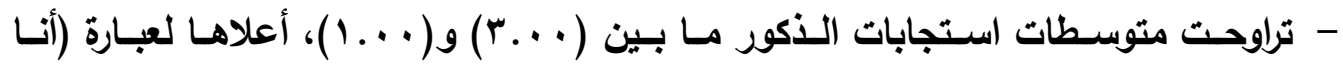
معروف بأني منظم عندما أنهمك في حل مشكلة مـا)، وأدناهـا لعباراتي (أنظر فقط إلى الحقائق التي تدعم معتقداتي، ولا أنظر إلى الحقائق التي تتعارض معها- لست بحاجة

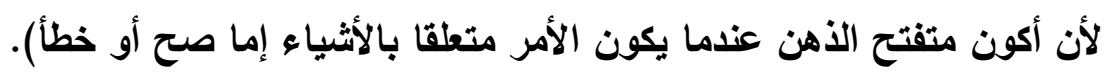


- كما يتضح من الجدول السابق أن قيمة المتوسط العام لاستجابات أفراد العينـة من الإناث

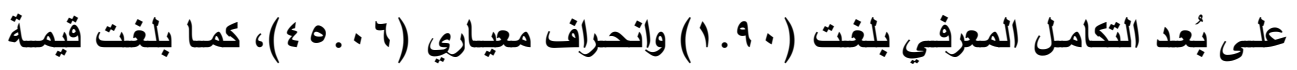

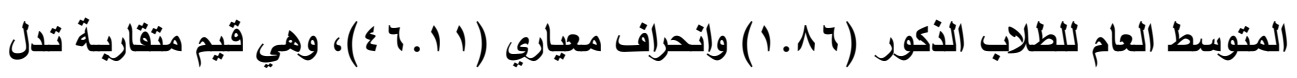
على عدم وجود فروق بين الإناث والذكور في متوسطات درجات استجابتهم على بُعد

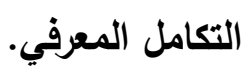
- وللتحقق مما سبق تم استخدام اختبار Z لادراسـة الفروق بين الذكور والإناث من أفراد العينة في أبعاد مقياس الاففية العقلية على النحو التالي:

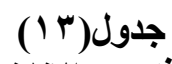

اختبار Z لاراسة الفروق بين الأكور والإناث في أبعاد مقياس الدافعية العقلية

\begin{tabular}{|c|c|c|c|c|c|c|}
\hline \multirow[b]{2}{*}{ مستوي } & \multirow[b]{2}{*}{ قالمحسوبة } & \multicolumn{2}{|c|}{ الذكور } & \multicolumn{2}{|c|}{ الإناث } & \multirow[b]{2}{*}{ ألافعية العقياس } \\
\hline & & الانحراف & الحستوسي & الالتحراف & الحستوسي & \\
\hline غير دالة & 0.587 & $\leqslant 0 . .0$ & 1.87 & $\leq \varepsilon .1$ & 1.97 & التركيز العقلي \\
\hline دالة & -3.174 & or.v. & 2.86 & $\varepsilon \wedge . \wedge 1$ & 2.52 & التوجه نحو \\
\hline غير دالة & -0.809 & $\varepsilon \wedge . r q$ & 2.60 & $\varepsilon V . r$. & 2.54 & حل المشكلات \\
\hline غير دالة & 0.205 & $\{7.11$ & 1.86 & $\leqslant 0.97$ & 1.90 & المعرفي \\
\hline
\end{tabular}

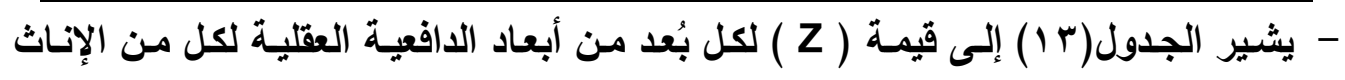

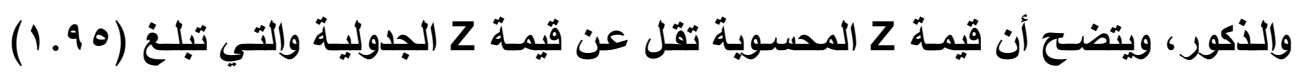

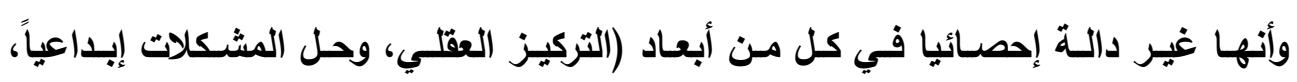

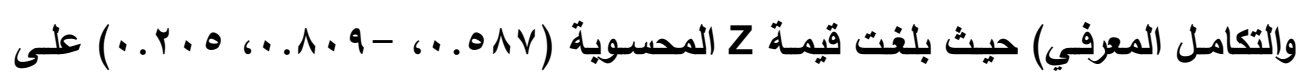
التوالى.

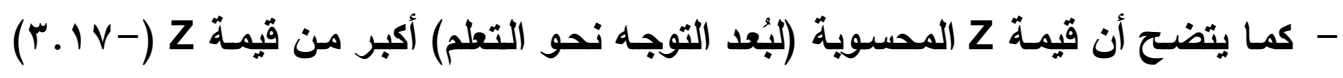

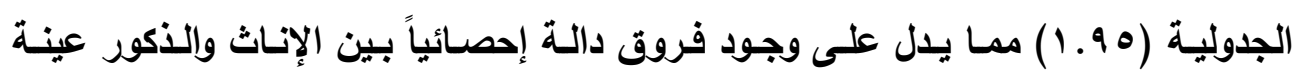

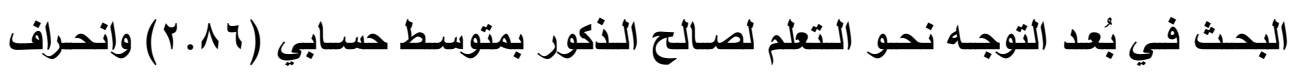

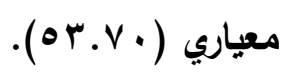


- مما سبق يتضح تحقق الفرض الثاني جزئياً القائل:(لا توجد فروق دالة إحصائياً بين

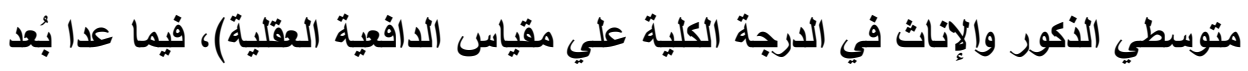
التوجه نحو التعلم لصالح الذكور.

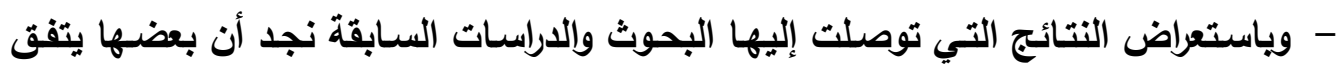

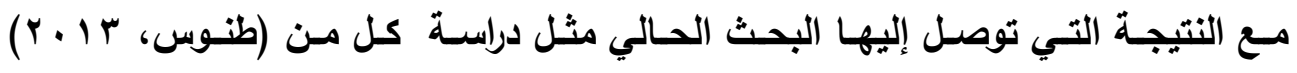

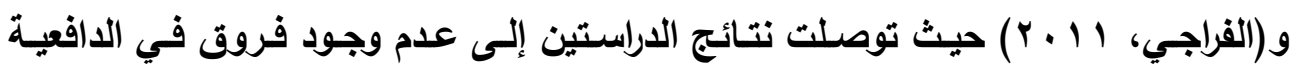

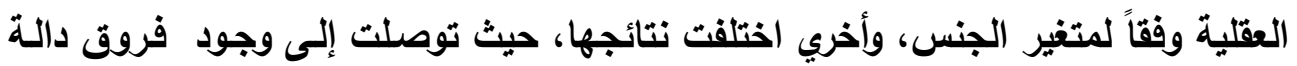

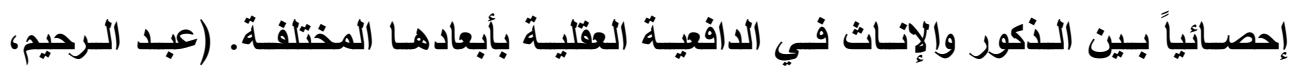

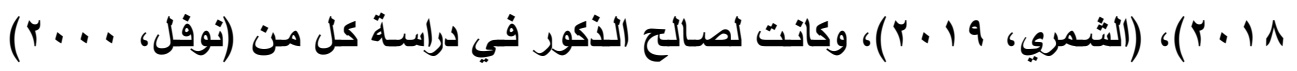

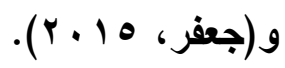

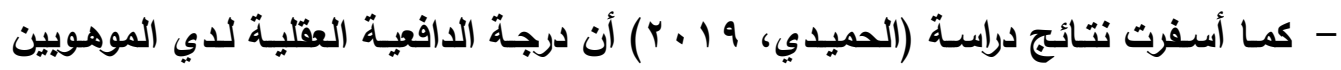

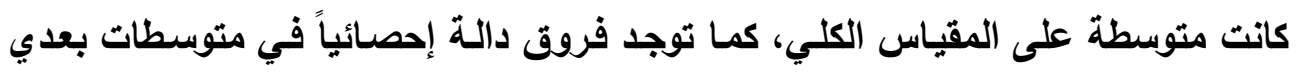

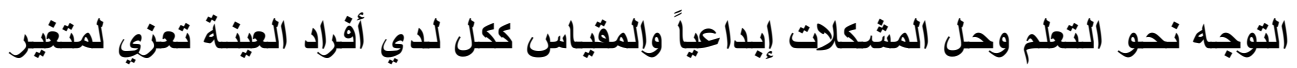
النوع لصالح الإناث. - وكسان مستوي الدافعيـة لـدي الطالبـات عينـة الاراسـة جيد في دراسـة (مجيد وعبد الله،

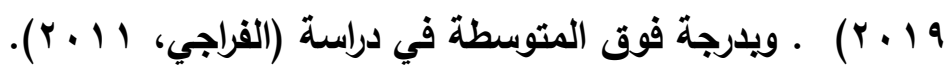

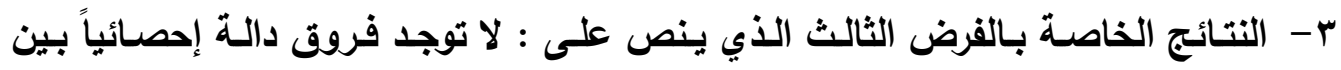

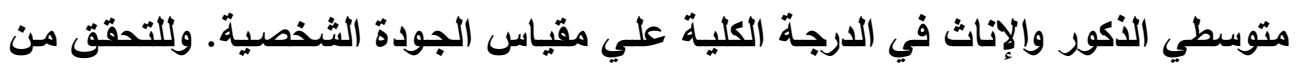
صحة هذا الفرض تم حساب المتوسطات الحسابية والانحرافات المعيارية لاستجابات أفراد

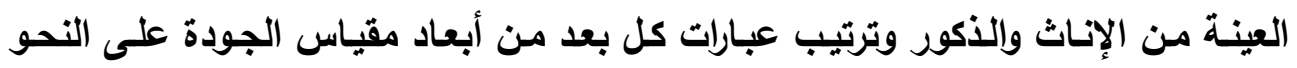
التإلىى: 


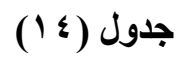

المتوسط الحسابي والانحراف المعياري لارجات استجابات أفراد العينة الخاصة بيُعد سمات الثخصية

الإيجابية إنجات

\begin{tabular}{|c|c|c|c|c|c|c|c|}
\hline \multirow[b]{2}{*}{ الترتيب } & \multicolumn{2}{|c|}{ الذكور } & \multirow[b]{2}{*}{ الترتيب } & \multicolumn{2}{|c|}{ الإناث } & \multirow[b]{2}{*}{ العبارات } & \multirow{2}{*}{$\sum_{0.0}^{\cdot 9}$} \\
\hline & الانحراف & الحستوسط & & الالحعراف & المستوسط & & \\
\hline$r$ & 45.53 & 2.67 & 8 & 45.94 & 2.54 & أثق بقدراتي في أصعب & 1 \\
\hline v & 38.16 & 2.01 & 11 & 40.89 & 2.00 & أستطيع التحكم بانفعالاتي & r \\
\hline$r$ & 45.53 & 2.67 & 5 & 51.74 & 2.73 & أقوم بتأدية دوري في أي & $r$ \\
\hline 1 & 40.03 & 2.33 & 10 & 42.65 & 2.37 & 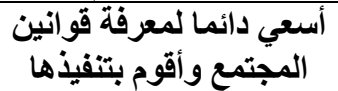 & $\varepsilon$ \\
\hline 0 & 40.16 & 1.84 & 9 & 45.59 & 2.18 & أشعر بالهـاو عشكلة. & 0 \\
\hline r & $\mathbf{5 0 . 2 0}$ & 2.83 & 8 & 45.94 & 2.54 & أعتقد أنتي ذَّ شخصية. & 7 \\
\hline$\varepsilon$ & 43.55 & 2.49 & 6 & 49.21 & 2.73 & أتقبل آراء الآخرين حتى لو أفكاري. & v \\
\hline$r$ & 45.53 & 2.67 & 6 & 49.21 & 2.73 & الحيوية وتحمل بقل كبيز منئية & $\wedge$ \\
\hline 1 & $\mathbf{5 7 . 5 2}$ & 3.00 & 1 & 60.26 & 3.00 & لل أبذل قصول إلى تحقيقي جهائي & 9 \\
\hline r & $\mathbf{5 0 . 2 0}$ & 2.83 & 4 & 52.20 & 2.82 & أبادر بحل المشكلات التي دراستي. & 1. \\
\hline$r$ & $\mathbf{5 0 . 2 0}$ & 2.83 & 6 & 49.21 & 2.73 & أنظر إلى المشَكلات لتحسين & 11 \\
\hline$r$ & 45.53 & 2.67 & 3 & 55.93 & 2.91 & من أولوياتي الاهتمام & ir \\
\hline r & $\mathbf{5 0 . 2 0}$ & 2.83 & 2 & 55.94 & 2.82 & أشعر بالرضا عن مظهري & ir \\
\hline$r$ & 45.53 & 2.67 & 7 & 47.10 & 2.64 & أنا شختف الظروف. & 1\{ \\
\hline - & 46.28 & 2.60 & - & $\leqslant 9 . \leqslant Y$ & 2.62 & المتوسط العام للبعد & \\
\hline
\end{tabular}

- يشير جدول (؛ 1) إلى متوسطات استجابات أفراد العينة من الذكور والإنـاث على بُعد

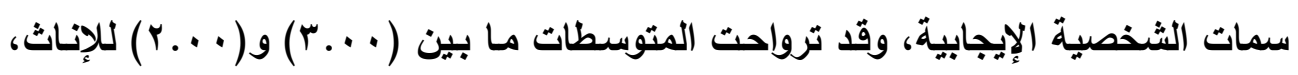

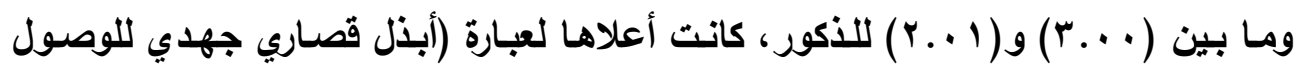


إلى تحقيق طموحاتي)، وأدناهـا لعبارة (أستطيع التحكم بانفعالاتي بسهولة) حيث حصلتا على نفس الترتيب لاي كل من الإناث والأكور . - كما يتضح من الجدول السابق أن قيمة المتوسط العام لاستجابات أفراد العينـة من الإناث

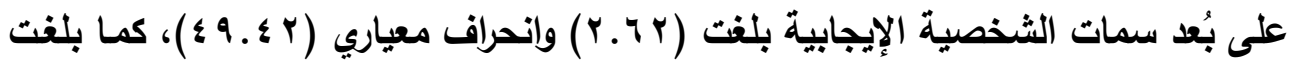

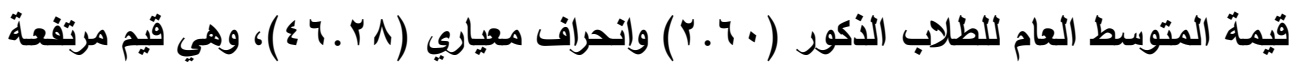
ومتقارية تدل على عدم وجود فروق بين الإناث والذكور في متوسطات درجات استجابتهم على بُعد سمات الشخصية الإيجابية، وأنهم يتسمون بسمات الشخصية الإيجابية.

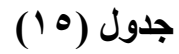

المتوسط الحسابي والاتحراف المعياري لارجات استجابات أفراد العينة الخاصة ببُعد العلاقات الإنسانية الجيدة البنابات

\begin{tabular}{|c|c|c|c|c|c|c|c|}
\hline \multirow[b]{2}{*}{ الترتيب } & \multicolumn{2}{|c|}{ الأكور } & \multirow[b]{2}{*}{ الترتيب } & \multicolumn{2}{|c|}{ الإناث } & \multirow[b]{2}{*}{ العبارات } & \multirow{2}{*}{ العبارة } \\
\hline & المعياري & الحستابي & & الالانحراف & الحستوسطي & & \\
\hline r & 50.20 & 2.83 & r & 52.20 & 2.82 & أعندر للآخرين & 10 \\
\hline 1 & $\mathbf{5 7 . 5 2}$ & 3.00 & $\varepsilon$ & 47.10 & 2.64 & ألتعرين كثيرا. & 17 \\
\hline 1 & 57.52 & 3.00 & 0 & 45.50 & 2.55 & أجوانب الإليجّابية & iv \\
\hline$\mu$ & 45.53 & 2.67 & r & 52.20 & 2.82 & عندما يخطئوني & 11 \\
\hline 1 & 57.52 & 3.00 & 1 & 55.93 & 2.91 & حقوق وواجنبات أحرين & 19 \\
\hline$\varepsilon$ & 43.75 & 2.50 & $r$ & 49.21 & 2.73 & أكون سعليدا جدا & r. \\
\hline r & 50.20 & 2.83 & r & 52.20 & 2.82 & الآخرين بإيجابية & r \\
\hline$r$ & 45.53 & 2.67 & 7 & 44.97 & 2.46 & أميل إلى الاختلاط. & rr \\
\hline- & $\mathbf{5 0 . 9 7}$ & 2.81 & - & 49.92 & 2.72 & توسط العام & \\
\hline
\end{tabular}

- يشير جدول (0 10) إلى متوسطات استجابات أفراد العينـة من الذكور والإنـاث على بُعد

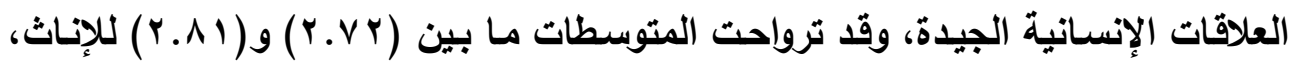


كانت أعلاهـا لعبارة (أحرص على حقوق وواجبات الآخرين.)، وأدناهـا لعبارة (أميل إلى (الاختلاط بالناس).

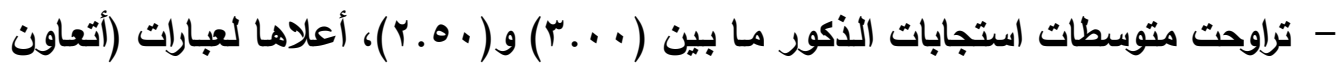
مـع الآخرين كثيرا- أركز على الجوانب الإيجابية في شخصية الآخرين - أحرص على حقوق وواجبات الآخرين)، وأدناها لعبارة (أكون سعيدا جدا بين زملائي). - كما يتضح من الجدول السابق أن قيمة المتوسط العام لاستجابات أفراد العينـة من الإناث

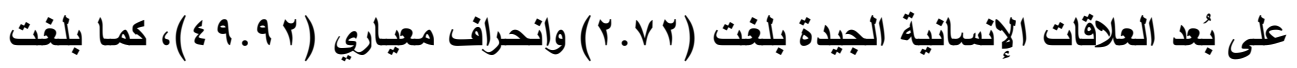

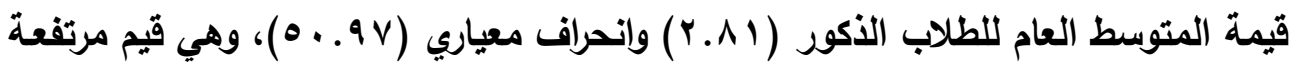
ومتقاربة تدل على عدم وجود فروق بين الإناث والذكور في متوسطات درجات استجابتهم على بُعد العلاقات الإنسانية الجيدة. جدول (17) المتوسط الحسابي والانحراف المعياري لارجات استجابات أفراد العينة الخاصة بيعُد أداء العمل الفائق

\begin{tabular}{|c|c|c|c|c|c|c|c|}
\hline \multirow[b]{2}{*}{ الترتيب } & \multicolumn{2}{|c|}{ الأكور } & \multirow[b]{2}{*}{ الترتيب } & \multicolumn{2}{|c|}{ الإناث } & \multirow[b]{2}{*}{ العبارات } & \multirow{2}{*}{ العبارة } \\
\hline & الالحعراف & الحسابي & & الالحعراف & الحسابي & & \\
\hline$r$ & 35.50 & 2.67 & $r$ & 47.82 & 2.82 & المدرسيّة على أكملي وجلي & rr \\
\hline$r$ & 35.50 & 2.67 & v & 25.63 & 2.46 & أنجز كافة الواجبات المحدة. & $r \varepsilon$ \\
\hline 1 & 61.19 & 3.00 & 7 & 35.59 & 2.64 & 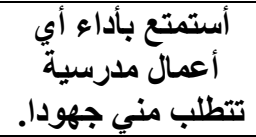 & ro \\
\hline$\varepsilon$ & 30.59 & 2.50 & 0 & 40.95 & 2.73 & الدراسية بدقةقة & צ' \\
\hline r & 46.49 & 2.83 & r & 55.65 & 2.91 & جميع زملاني على أنصائي & rV \\
\hline r & 46.49 & 2.83 & $r$ & 47.82 & 2.82 & 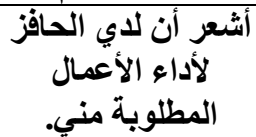 & rA \\
\hline r & 46.49 & 2.83 & 7 & 35.59 & 2.36 & الدالصية التيّي تتسم & rq \\
\hline 1 & 61.19 & 3.00 & $r$ & 55.65 & 2.91 & أحرص على تطوير & $r$. \\
\hline
\end{tabular}




\begin{tabular}{|c|c|c|c|c|c|c|c|}
\hline \multirow[b]{2}{*}{ الترتيب } & \multicolumn{2}{|c|}{ الأكور } & \multirow[b]{2}{*}{ الترتيب } & \multicolumn{2}{|c|}{ الإناث } & \multirow[b]{2}{*}{ العبارات } & \multirow{2}{*}{ العبارة } \\
\hline & الالحعراف & الحستوسي & & الالمعراف & الحستبي & & \\
\hline & & & & & & أدائي التعلنمي. & \\
\hline 1 & 61.19 & 3.00 & 1 & 64.08 & 3.00 & 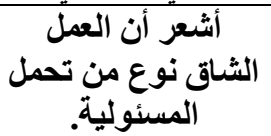 & $r$ \\
\hline 1 & 61.19 & 3.00 & $r$ & 47.82 & 2.82 & أنطلّع دائما لتطوير & rr \\
\hline r & 46.49 & 2.83 & $\varepsilon$ & 46.76 & 2.73 & فصلى ومدرسنى نظافة. & rr \\
\hline$r$ & 46.49 & 2.83 & $\varepsilon$ & 46.76 & 2.73 & خطأ في عملي أبتاب أي & $r \varepsilon$ \\
\hline - & 48.24 & 2.83 & - & $\leqslant 0 . \wedge 0$ & 2.74 & المتوسط العام " & \\
\hline
\end{tabular}

- يشير جدول (7 1 ) إلى متوسطات استجابات أفراد العينة من الذكور والإنات على بُعد أداء

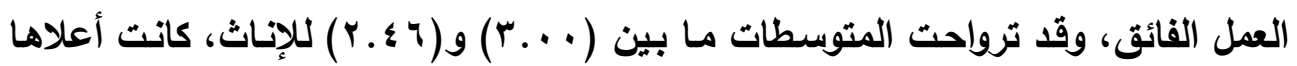
لعبـارة (أثـعر أن العمـل الثـاق نـوع مـن تحمـل المسـولية)، وأدناهـا لعبـارة (أنجـز كافـة الواجبات بالمواعيد المحددة).

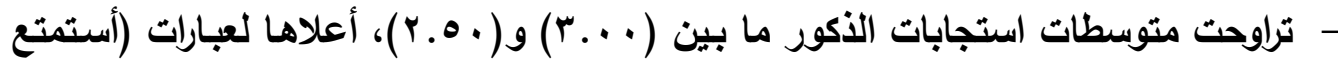
بأداء أي أعمال مدرسية تتطلب مني جهودا - أحرص على تطوير أدائي التعلدي- أثـعر أن العمل الثـاق نـوع من تحمـل المسئولية- أتطلـع دائمـا لتطوير ذاتـي علميـا)، وأدناهـا لعبارة (أحدد مهامي الدراسية بدقة وعناية). - كما يتضح من الجدول السابق أن قيمة المتوسط العام لاستجابات أفراد العينـة من الإناث

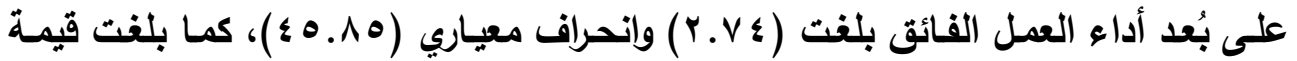

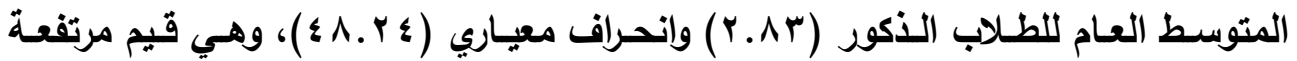
ومتقارية تدل على عدم وجود فروق بين الإناث والذكور في متوسطات درجات استجابتهم على بُعد أداء العمل الفائق. - وللتحقق مما سبق تم استخدام اختبار Z لاراسـة الفروق بين الذكور والإناث من أفراد العينة في أبعاد مقياس الجودة الشخصية على النحو التالي: 
(iv) جدول

اختبار Z لاراسة الفروق بين الذكور والإناث في أبعاد مقياس الجودة الثخصية

\begin{tabular}{|c|c|c|c|c|c|c|}
\hline \multirow[b]{2}{*}{ مستوية } & \multirow{2}{*}{ المحسوبة Z } & \multicolumn{2}{|c|}{ الأكور } & \multicolumn{2}{|c|}{ الإناث } & \multirow{2}{*}{ أبعاد مقياس } \\
\hline & & الالاتحرافي & الحسابي & المعياري & الحستوسبي & \\
\hline غير & $\because Y \otimes V$ & 46.28 & 2.60 & $\leqslant 9 . \leqslant r$ & 2.62 & الثخصية \\
\hline دالةير & -1.177 & 50.97 & 2.81 & 49.92 & 2.72 & الإلعلاقيةت \\
\hline غالةّ & -1.332 & 48.24 & 2.83 & $\leqslant 0, \wedge 0$ & 2.74 & أداءائق العمل \\
\hline
\end{tabular}

- يشير جدول ( V ) إلى قيمسة Z لكل بُعد من أبعاد الجودة الشخصية لكل من الإنـاث

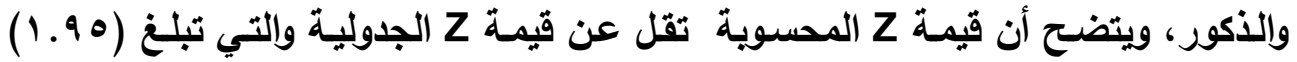
وأنها غير دالة إحصـائيا في كل من أبعاد الجودة الشخصية ممـا يدل على عدم وجود فروق في أبعاد الجودة الثخصية بين الأكور والإناث وفقاً لمتغير النوع،. - مما سبق يتضح تحقق الفرض الثالث القائل:" لا توجد فروق دالة إحصائياً بين متوسطي لإني الأكور والإناث في الارجة الكلية علي مقياس الجودة الشخصية " - وهو ما يتعارض مع دراسة (مصطفي، 9 ( ب r) التي توصلت إلى وجود فروق في مكونات الجودة الشخصية للدي طلبـة الجامعة بحسب النـوع، ودراسـة (البيطـار، 19 ـ ب) حيث توصلت إلى وجود فروق بين الذكور والإنـاث في بعض السـمات الثخصية التي تميز الطلاب المتفوقين دراسياً. الاستنتثاجات ا - يتمتع الطلاب المتفوقون دراسياً بمستوي عال من الدافعية العقلية، ويتميزون بالتركيز

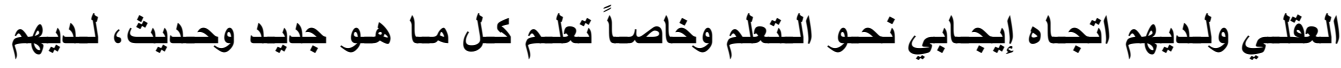
استعدادات ذات مستوي عال على التفكير الإبداعي في حل المشكلات التي تواجههم، ولديهم سعة فهم واستيعاب للمعلومات. r - وعلي الجانب الثخصي يتميزون بلرجة عالية من تقدير الذات والثقة والاعتمـاد علي النفس، والمثابرة وتحمل المسؤولية. يعتبر ارتفـاع مستوي الدافعية لديهم هو الأسـاس في لوني 
اكتسـابهم سمات الشخصية الإيجابية وإنجاز العمل بإتقان، كمـا يتميزون بالثبات الانفعالي

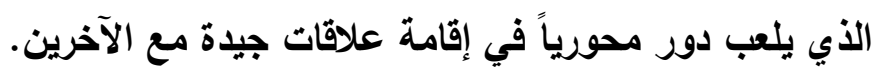

\section{توصيات البحث}

1 - الاهتمـام بتنميـة الدافعية العقلية لـدي الطلاب المتفوقين والعـاديين حتى تسني لهم مواجهة التفجر المعرفي التكنولوجي السريع والمتلاحق والمستمر. r - استحداث برامج تدريسية تهدف إلى تدريب وتتميـة الدافعيـة العقلية وتعزيز الجودة الثخصية لاي الطلاب بوجه عام. ب- استخدام وسائل تدريسية مختلفة وحليثة تساعد في تنمية الدافعية العقلية لدي كل من المتفوقين والعاديين من الطلاب. ع - إغتـاء المنـاهج والكتب الدراسية بموضـوعات تبرز وتركز على الجوانب والسـمات الشخصية الإيجابية لدي الطلاب.

البحوث المقترحة في ضوء النتائج التي توصل إليها البحث الحالي يمكن اقتراح إجراء الدراسات الآتية: - الدافعية العقلية وعلاقتها بالتحصيل الدراسي لاي الطلاب العاديين. - - الجودة الثخصية وعلاقتها بالتحصيل الدراسي لدي الطلاب العاديين. - فاعلية برنامج مقترح قائم على التفكير النقدي في تنمية الدافعية العقلية.

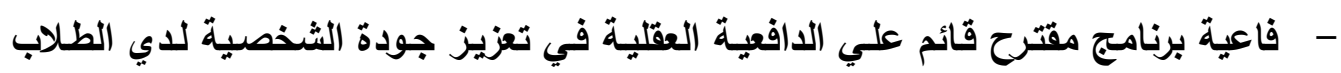
العاديين. 


\section{المراجع}

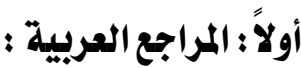

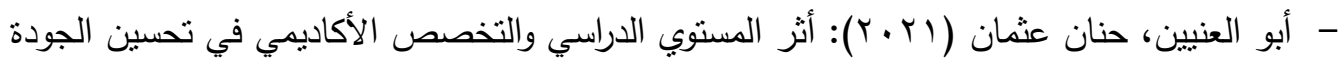

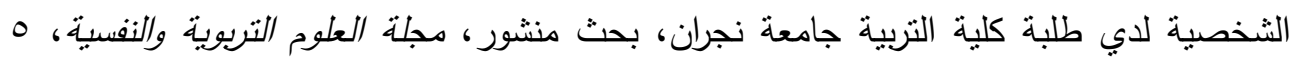

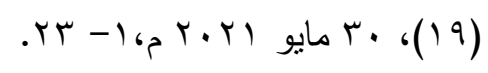

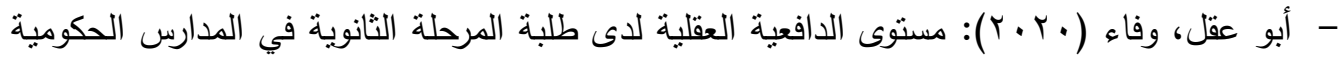

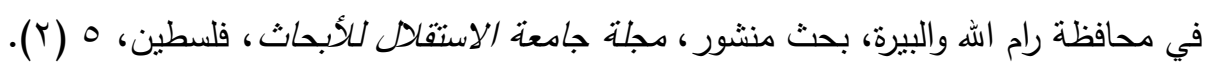

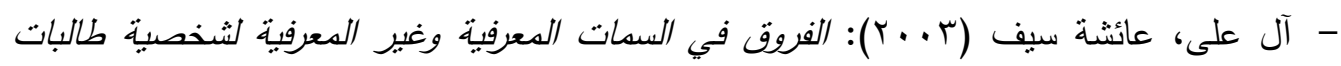

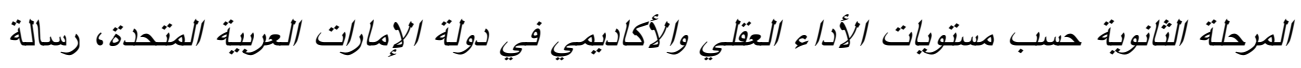

ماجستير ، كلية الدراسات التربوية، جامعة الخليج العربي، البحرين.

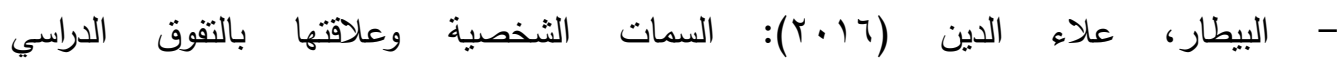

\section{https://psycho.sudanforums.net/tr $10 \wedge$-topic}

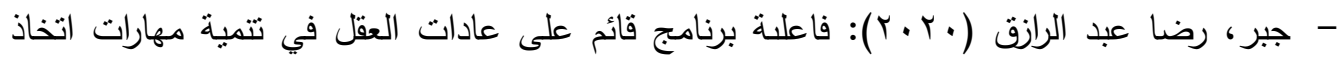

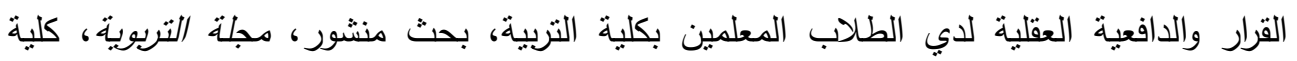

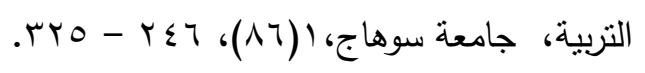

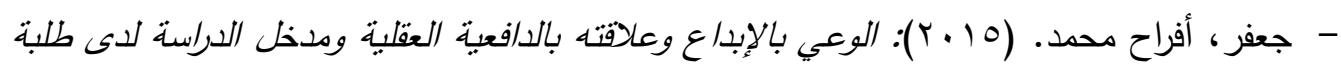

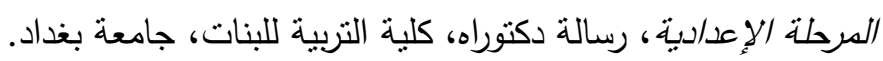

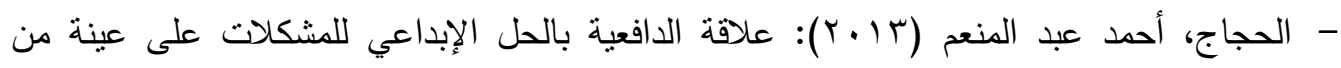

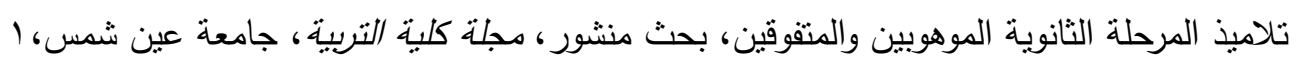
$.90 \leq-9) \leq 6(r v)$

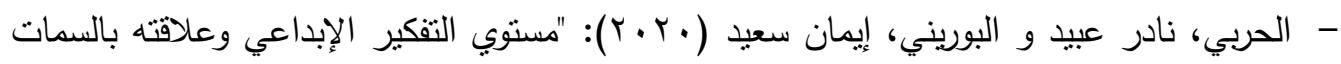

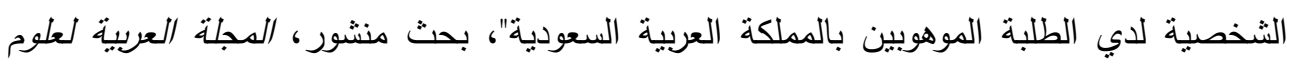

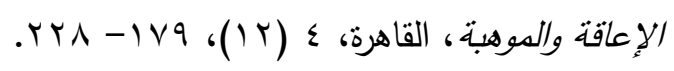

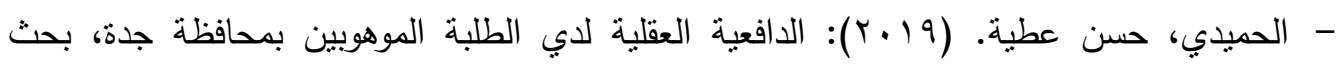

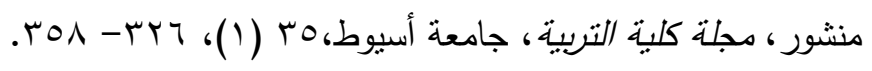

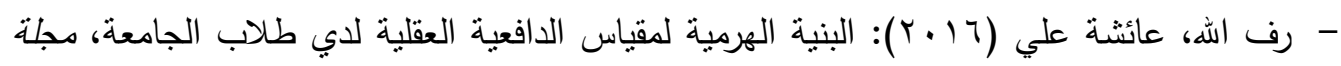

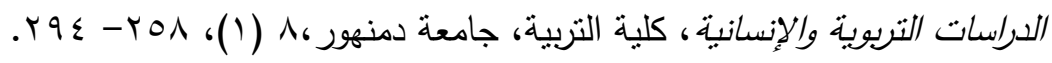


- الثمري، هديل على.(9 (r): الدافعية العقلية وعلاقتها بالتفاخر الأصيل لدى طلبة مدارس

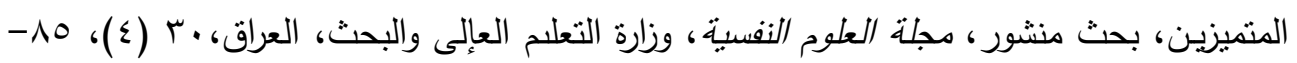

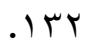

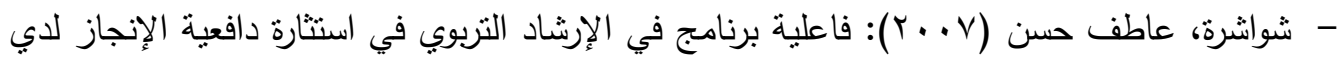
طالب يعاني من تدني الدافعية في التحصيل (دراسة حالة)

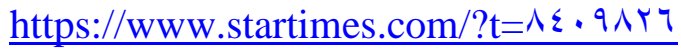
- طنوس، إياد سهيل (r (ץ): أساليب التفكير وعلاقتها بالدافعية العقلية لدى الطلبة، رسالة ماجستير ، كلية العلوم التربوية والنفسية بجامعة عمان العربية، الأردن.

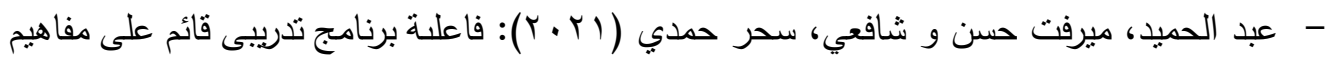

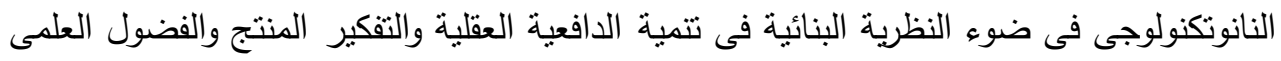
لدى طلاب كلية التربية شعبة الكيمياء، بحث منشور ، مجلة البحث العلمي في التربية، كلية البنات

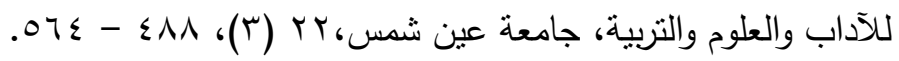

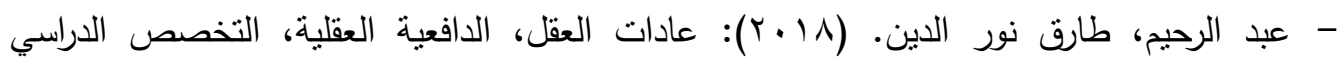
والجنس كمتغيريات تتبؤية لكفاءة التعلم الإيجابية لدى طلاب جامعة سوهاج، بحث منشور ، الدجلة

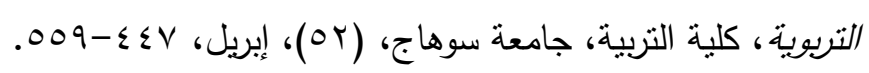

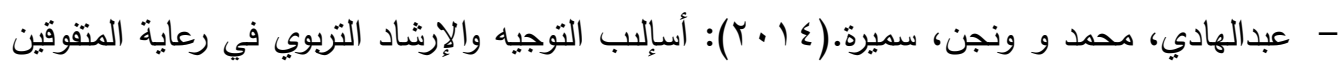

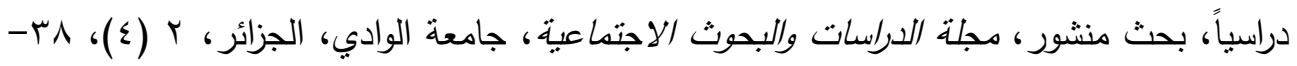
.09 - على، قيس محمد و حموك، وليد سالم (؟ ( ب): الدافعبة العقلية رؤية جديدة. الأردن: مركز دييونو لتعليم التفكير - العنان.

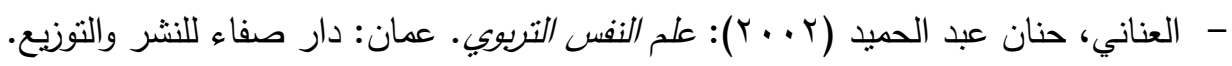

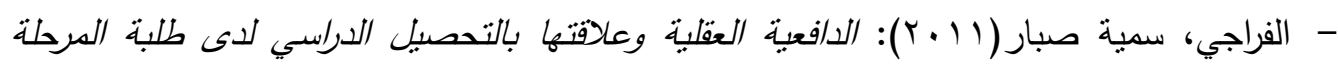
الإعدادية. رسالة ماجستير، كلية التربية، أبن الهيثم، بغداد.

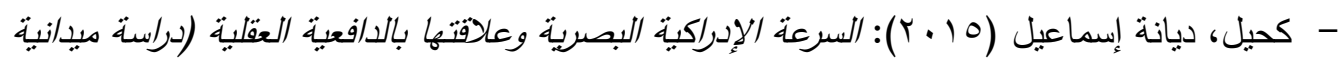

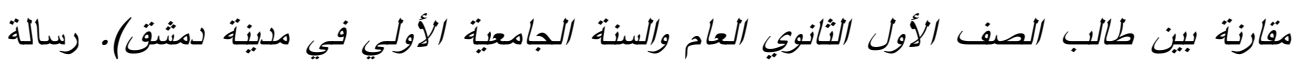
ماجستير ، كلية التربية، جامعة دمشق.

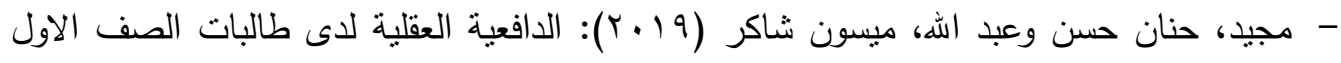

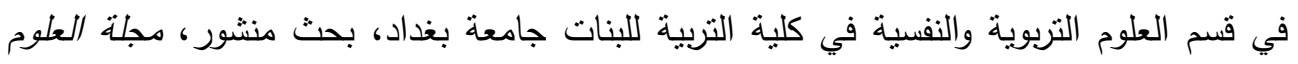

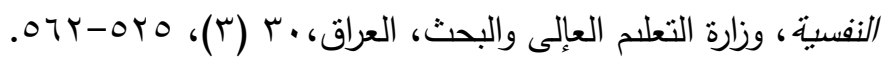




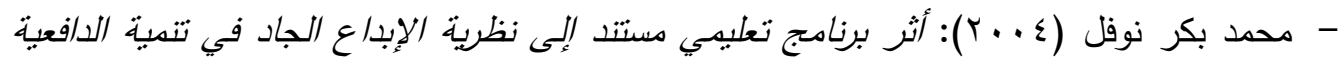
العقلية لدى طلبة الجامعة من ذوي السيطرة الدماغية اليسرىى. رسالة ماجستير، كلية الدراسات التزبوية العليا، جامعة عمان العربية، الأردن.

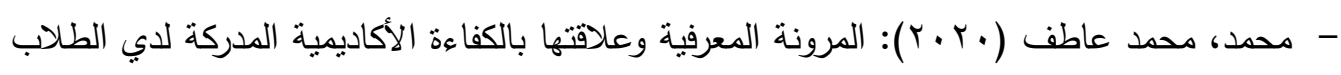

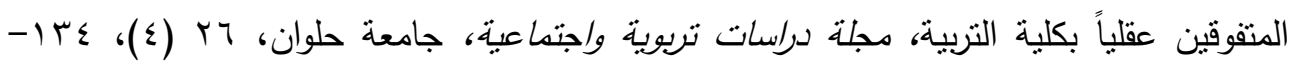
.177

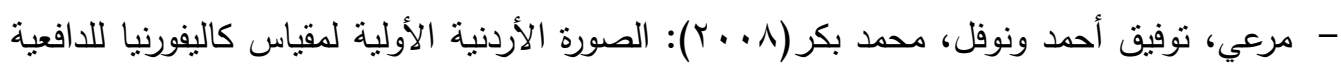

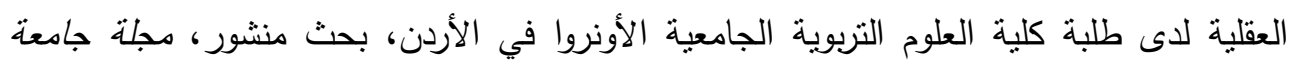

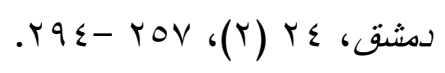

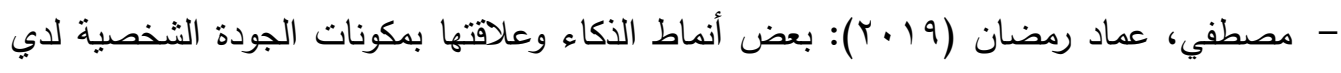

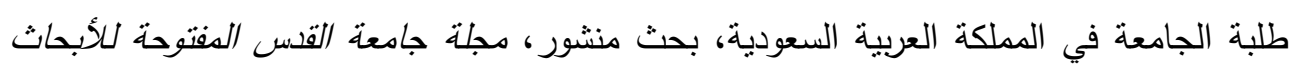

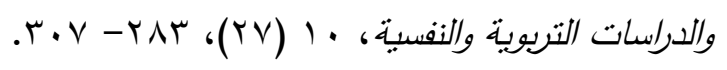

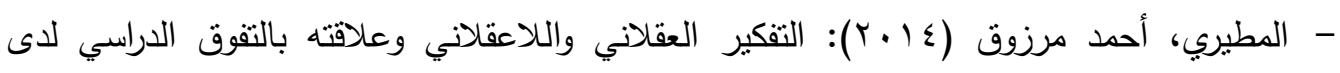

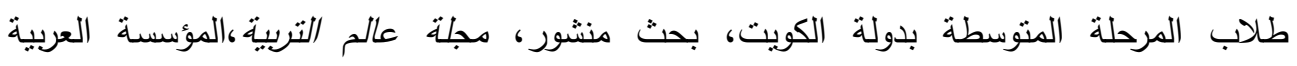

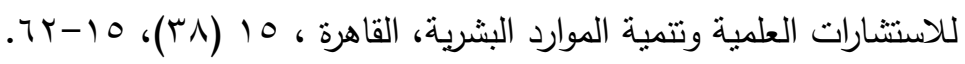

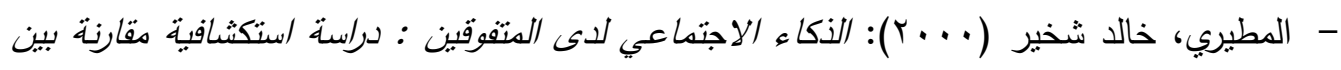

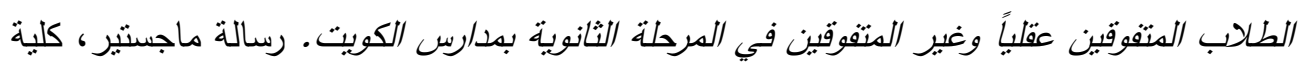
الدراسات العلا، جامعة الخليج العربي، البحرين.

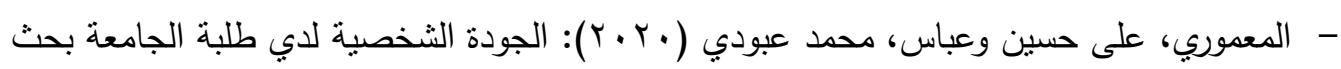

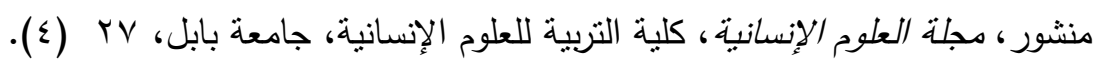
https://www.iasj.net/iasj/article//909). - النجار، محمد يونس (1) •ب): درجة معارسة مديري الدارس الحكومية في محافظة الخليل لمعايير الجودة الثخصية من وجهة نظر الدعلدين، رسالة ماجستير، كلية العلوم التزبوية، جامعة القسا.

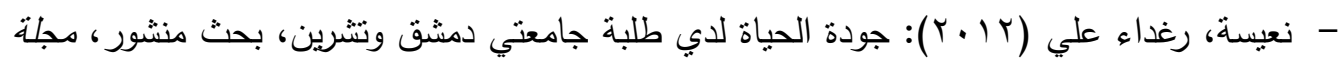

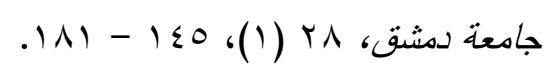

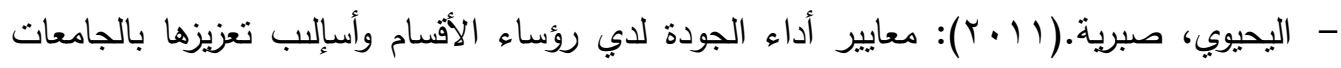

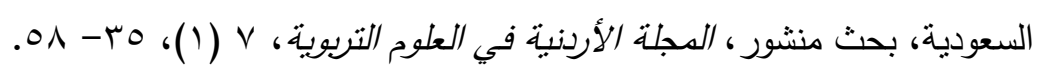




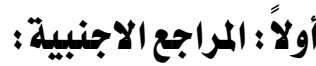

- Davies, L, (2000). Addressing Emotional Intelligence through the Teaching of Thinking Skill, San Francisco: Jossey Bass INC.

- Finkelman, A. \& Kenner, C. (2009): Professional Nursing Concepts: Competencies for Quality Leadership. New York: Jones \& Bartlett Publishers.

- Garcia, T. Pintrich, P. R. (1992): Critical Thinking and Its Relationship to Motivation, Learning Strategies, and Classroom Experience, Paper presented at the Annual Meeting of the American Psychological Association (100th, Washington, DC, August 14-18.

https://files.eric.ed.gov/fulltext/EDr01 $7 \leqslant$ r.pdf

- Govern, D. (2001): Motivation: Theory, Research and Applications, Thomson, Wadsworth, Australia.

- Gratz, D. B. (2009): The Peril and Promise of Performance Pay: Making Education Compensation Work. New York: Rowman \& Littlefield Education. Halan, Y. C.

- Kurum .E.Y (2007). The effect of motivation factors on the foreign language success of students at the Turkish military academy, NovitasROYAL (Research on Youth and Language), 2011, 5 (2), 299-307.

- Lussier, R. (2009): Human relations in organizations: Applications and skill building. New York: McGraw-Hill/Irwin.

- McInerney D, M \& Etten, Sh, V.(2001): Research on socio cultural influences on motivation and learning, vol 1, chap3,.publisher. IAP.West Putnam, USA.

- Pitt, V.; Powis, D.; Levett, J. T. \& Hunter, S. (2014). The Influence of Personal Qualities on Performance and Progression in a Pre-registration Nursing Programme. Nurse Education Today, Volume 34, Issue 5, May 2014, 866-871.

- Vermeer, H. J., Boekaerts, M., \& Seegers, G. (2000): Motivational and gender differences: Sixth-grade students' mathematical problem-solving behavior. Journal of educational psychology, 92, 308-315.

- Zaffron, S. \& Dave, L. (2009): The Three Laws of Performance: Rewriting the Future of your Organization and your Life. New York: Jossey Bass.

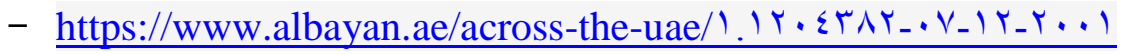

